\title{
Evaluation of Antioxidant, Toxicological and wound healing Properties of Hibiscus rosa-sinensisL. (Malvaceae) ethanolic leaves extract on different Experimental animal models
}

\author{
Sumanta Mondal ${ }^{1 *}$, Debjit Ghosh ${ }^{2}$, Nuni Sagar ${ }^{1}$, Seru Ganapaty ${ }^{1}$ \\ ${ }^{1}$ GITAM Institute of Pharmacy, GITAM University, Visakhapatnam, Andhra Pradesh, INDIA. \\ ${ }^{2}$ Department of Chemistry, GITAM Institute of Science, GITAM University, Visakhapatnam, Andhra Pradesh, INDIA.
}

\begin{abstract}
Objective: The present research article was conducted to study the toxicity profile, antioxidant potential and wound healing activity of ethanolic leaves extract of Hibiscus rosa-sinensis L. (ELEHR). Materials and Methods: In-vitro antioxidant properties were assessed using DPPH radical scavenging activity, Nitric oxide scavenging activity, and superoxide radical scavenging activity. Acute toxicity was performed to study the general behavioural pattern of mice and sub-acute toxicity studies were performed to study the toxic effects of the test extract on different biochemical and haematological parameters, body and organ weight and histopathology of liver, pancreas and kidney. Wound healing properties was evaluated using excision, incision, dead space and burn wound model. Results: Strong antioxidant activity was recorded in a concentration dependant manner for ELEHR in all three models. The toxicological evaluation of ELEHR revealed that it has a reasonable safety profile as there was no severe alteration. In the evaluation of wound healing properties, ELEHR treated group showed an enhanced wound contraction rate and epithelisation period in both excision and burn wound models, whereas in incision wound model wound breaking strength was significantly increased in extract treated group compared to control. Histology of the skin of healed excised wound also showed restoration to normal architecture in extract treated group. Wound healing activity was further substantiated by enhanced antioxidants and connective tissue markers which were estimated in dead space wound model. Conclusion: Thus ELEHR proved to be effective in wound healing which may be because of strong antioxidant properties and also possesses reasonable safety profile.
\end{abstract}

Key words: Antioxidant, Burn injuries, Hibiscus rosa-sinensis, Normal wound healing, Toxicity profile

\section{INTRODUCTION}

The use of plants for healing purposes predates human history and forms the source of current modern medicine. Many conventional drugs have been originated from plant sources. ${ }^{1}$ In the current scenario, the demand for herbal products is growing exponentially throughout the world and major pharmaceutical companies are currently conducting extensive research on plant materials for their potential therapeutic value. $^{2}$

Many medicinal plants have been evaluated for their antioxidant properties. Natural antioxidants either in the form of raw extracts or their chemical constituents are very effective to prevent the damage caused by oxidative stress. ${ }^{3}$ Reactive oxygen species (ROS) and other oxidants are responsible for causing
Submission Date : 09-06-2016 Revision Date : :17-08-2016 Accepted Date : 15-09-2016

DOI: 10.5530/ijper.50.4.15

Correspondence:

Dr. Sumanta Mondal GITAM Institute of Pharmacy, GITAM University, Visakhapatnam, Andhra Pradesh, India

Phone no: -

+91-9703615761

E-mail: logonchemistry@ yahoo.co.in

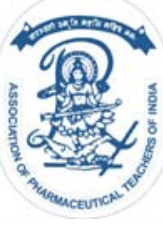

www.ijper.org 
numerous disorders and diseases which has brought the attention of scientists for investigating medicinal plants for their antioxidant properties. ${ }^{4}$ Medicinal plants may be beneficial to humans as they have several bio-active compounds to cure diseases but the potential toxicity of these phyto-constituents has not been well established. ${ }^{5}$ There are very little scientific evidences on the safety and efficacy of herbal drugs to the increase in number of its users which raised concerns regarding toxicity and detrimental effects of these herbal remedies. Thus there is a need to evaluate the safety and efficacy of these plants thoroughly to maximize their benefits for mankind. ${ }^{6}$ Hibiscus rosa-sinensis (Linn.) is an evergreen woody, glabrous, showy shrub 5-8 feet in height belonging to family Malvaceae. It is commonly referred as Chinese hibiscus, China rose and shoe flower and is widely grown as an ornamental plant in tropical and subtropical regions of East Asia. ${ }^{7,8}$ Traditionally, the plant is reported to be used in the treatment of a variety of ailments. The leaves and flowers are observed to be promoters of hair growth and aid in healing of ulcers. The aerial parts of Hibiscus rosa-sinensis are used in treatment constipation and diarrhea. The leaves are used in curing skin diseases and fatigue. The powdered roots of the plant are used in treatment of menorrhagia and fresh juice of root is used in gonorrhea. The flowers of are used in treatment of epilepsy, diabetes, leprosy etc. In Ayurvedic medicine an infusion of petal is widely used as a demulcent refrigerant drink in fever. The flowers have also been found to be effective in the treatment of arterial hypertension and to have significant antifertility effect. Moreover, in India the herbal products in the market intended for hair growth include the extract of various parts of Hibiscus rosa-sinensis. There are several pharmacological activities reported on Hibiscus rosa-sinensis leaves such as antifungal, anti-inflammatory, hair growth promoting, analgesic, antipyretic, antibacterial, and in-vitro antioxidant activities. ${ }^{910,12}$ Many phyto-constituents were also isolated from various parts of Hibiscus rosa-sinensis like $\beta$-sitosterol, stigmasterol, taraxeryl acetate from leaves and stems. Quercetin-3-diglucoside, cyanidin3-sophoroside-5-glycosides, 3, 7-diglucoside, cyanidin-3, 5 -diglucoside have been isolated from deep yellow flowers of Hibiscus rosa-sinensis. ${ }^{11,12}$

Wound can be defined as a break in the cellular and anatomical architecture of body tissue that includes skin, mucus membrane, deeply lying tissues or surface of internal organs ranging from incision, laceration, abrasion, puncture, and closed wounds such as contusion, hematoma and crush. ${ }^{13}$ Normal wound healing response begins as soon as the tissue is injured. An inflammatory response occurs following the injury and the cells below the dermis begin to increase collagen production. Later, the epithelial tissue is regenerated. ${ }^{14}$

Burns are injuries to tissues caused by excessive heat, electricity, radioactivity or corrosive chemicals that destroy (denature) protein in the exposed cells. They permit microbial invasion and infection, loss of body fluid and loss of thermo regulation. ${ }^{15}$

Inappropriate treatment of the wounds may delay its healing, causing the area to become infected and subsequently resulting in chronic wounds. Few antimicrobial ointments such as silver sulfadiazine, mafenide, silver nitrate, povidone-iodine, mupirocin and bacitracin, are used to reduce the risk of infection in minor cuts and burns but these topical antimicrobials are not fully effective in treatment of wounds and may cause some side effects. ${ }^{16}$ Thus there is need to develop safer drugs to combat different types of wounds.

Literature available from all possible scientific sources revealed that the leaves of Hibiscus rosa-sinensis have not been evaluated for its toxicological effects and also its wound healing potential. Thus the present study is investigated to explore the antioxidant properties, toxicological effects and healing potential of ethanol extract from Hibiscus rosa-sinensis (Linn.) on excision, incision, dead space and burn wound model in Wistar albino rats.

\section{MATERIALS AND METHODS}

\section{Collection and authentication of plant materials}

The fresh leaves of Hibiscus rosa-sinensis (Linn.) were collected in the month of July, 2012 from the rural belt of Visakhapatnam district, Andhra Pradesh, India. The plant materials were then authenticated by Dr. M. Venkaiah, Professor (Retd.), Department of Botany, Andhra University, Visakhapatnam, Andhra Pradesh, India. A voucher specimen has been kept in our research laboratory for further reference.

\section{Preparation of extracts}

The collected plant materials were gently washed in tap water to remove dirt and then they were shade dried in the laboratory under room temperature $\left(24 \pm 2^{\circ} \mathrm{C}\right)$ for 3-4 weeks and protected from direct heat or sunlight. After complete drying of the plant materials they were pulverized by using a mechanical grinder followed by sieving (sieve no. 40) to obtain coarse powder. The powdered plant materials $(500 \mathrm{~g})$ were defatted with petroleum ether $\left(60-80^{\circ} \mathrm{C}\right)$ in a soxhlet extractor. The marc was then air-dried and extracted with ethanol $(90 \%)$, excess solvents were removed by rotary vacuum evaporator (Evator, Media Instrument Mfg. Co., Mumbai, 
India) and concentrated to obtain a dark greenish residue which was about $51.8 \mathrm{~g}$. The percentage yield was calculated by the following formula.

$$
\text { Percentage yield }=\frac{\begin{array}{c}
\text { weight of dry crude } \\
\text { extract obtained }(\mathrm{g})
\end{array}}{\begin{array}{l}
\text { Weight of plant material } \\
\text { before extraction }(\mathrm{g})
\end{array}} \times 100
$$

\section{Preliminary phytochemical tests}

Preliminary phytochemical studies of ELEHR were performed for determination of major phytochemical constituents using standard procedures. ${ }^{17,18}$

\section{In-vitro Antioxidant activities DPPH radical scavenging activity}

The free radical scavenging activity of ELEHR was assessed by 1,1-diphenyl-2-picrylhydrazyl(DPPH) radical scavenging assay according to the methods described by Shimada et al., 1992. ${ }^{19} 0.1 \mathrm{mMDPPH}$ solution was freshly prepared in ethanol and was used for the assay. Then, $1 \mathrm{~mL}$ of this solution was added to $2 \mathrm{~mL}$ of ELEHR solution at different doses of 200, 400, 600, 800 and $1000 \mu \mathrm{g} / \mathrm{mL}$. The mixture was shaken vigorously and kept in the dark at controlled room temperature $\left(25-28^{\circ} \mathrm{C}\right)$ for $30 \mathrm{~min}$. Then the absorbance was measured at $517 \mathrm{~nm}$ in a spectrophotometer. The degree of discoloration occurred in the samples indicates the free radical scavenging efficiency of the substances. The percentage of DPPH radical scavenging activity was calculated by the following formula.

$$
\% \text { inhibition of DPPH radical }=\left[\frac{A_{b r}-A_{a r}}{A_{b r}}\right] \times 100
$$

Where $A_{b r}$ is the absorbance before reaction and $A_{a r}$ is the absorbance after reaction has taken place.

\section{Nitric oxide (NO) scavenging activity}

Nitric oxide (NO) scavenging activity was performed according to methods described by Rai et al., 2006. ${ }^{20}$ $0.5 \mathrm{~mL}$ of $10 \mathrm{mM}$ sodium nitroprusside in phosphate buffered saline was added and mixed with $0.5 \mathrm{~mL}$ of different concentrations of ELEHR (200, 400, 600, 800 and $1000 \mu \mathrm{g} / \mathrm{mL}$ ) and control and incubated in the dark at room temperature $\left(25-28^{\circ} \mathrm{C}\right)$ for $150 \mathrm{~min}$. After $150 \mathrm{~min}$ of incubation, $0.5 \mathrm{~mL}$ of the incubated solution was withdrawn and mixed with $0.5 \mathrm{~mL}$ of Griess reagent $[(1.0 \mathrm{~mL}$ sulfanilic acid reagent $(0.33 \%$ sulfanilic acid in $20 \%$ glacial acetic acid incubated at room temperature for $5 \mathrm{~min}$ ) with $1 \mathrm{~mL}$ of naphthyl ethyl enediamine dichloride $(0.1 \% \mathrm{w} / \mathrm{v})]$. Then the mixture was incubated for $30 \mathrm{~min}$ at $25^{\circ} \mathrm{C}$. The absorbance of the chromophore formed was read at $540 \mathrm{~nm}$. The results were expressed as the percentage inhibition of nitric oxide. The amount of nitric oxide radical inhibition was calculated by the following equation:

$$
\% \text { inhibition of NO radical }=\left[\frac{A_{0}-A_{1}}{A_{0}}\right] \times 100
$$

Where $A_{0}$ is the absorbance before reaction and $A_{1}$ is the absorbance after reaction has taken place with Griess reagent.

\section{Superoxide radical scavenging activity}

Measurement of superoxide anion scavenging activity of ELEHR was based on standard methods. ${ }^{21,22}$ Superoxide radicals are generated in phenazine methosulphate (PMS)-nicotinamide adenine dinucleotide (NADH) systems by oxidation of NADH and assayed by the reduction of nitroblue tetrazolium (NBT). The superoxide radicals were generated in $3 \mathrm{~mL}$ of Tris- $\mathrm{HCl}$ buffer $(16 \mathrm{mM}, \mathrm{pH} 8.0)$ containing $1 \mathrm{~mL}$ of NBT $(50 \mu \mathrm{M})$ solution, $1 \mathrm{~mL}$ NADH $(78 \mu \mathrm{M})$ solution and $1 \mathrm{~mL}$ sample solution of ELEHR (200, 400, 600, 800 and $1000 \mu \mathrm{g} / \mathrm{mL}$ ) were mixed. The reaction was initiated by adding $1 \mathrm{~mL}$ of PMS solution $(10 \mu \mathrm{M})$ to the mixture. The reaction mixture was incubated at $25^{\circ} \mathrm{C}$ for $5 \mathrm{~min}$, and the absorbance was measured at $560 \mathrm{~nm}$ against blank samples, containing all the reagents except the PMS. The percentage inhibition of superoxide anion generation was calculated using the following formula:

$$
\% \text { inhibition }=\left[\frac{A_{0}-A_{1}}{A_{0}}\right] \times 100
$$

Where $A_{0}$ was the absorbance of the control, and $A_{1}$ was the absorbance of ELEHR.

\section{Experimental animals and housing conditions}

Swiss albino mice (20-25 g) of either sex were used for acute toxicity evaluation and Wistar albino rats (150-250 g) both male and female were used to evaluate wound healing potential, whereas for examination of sub-acute toxicity only male Wistar albino rats of 8-16 weeks old were taken. The animals were housed for at least one week in the laboratory animal room prior to testing and maintained in clean polypropylene cages (Temp: $25 \pm 2^{\circ} \mathrm{C}$, and $75 \%$ relative humidity) and fed with commercially pelleted rat diet $(\mathrm{M} / \mathrm{s}$ Hindustan Lever Ltd., Mumbai) and water ad libitum.

\section{Ethical approval}

All experimental protocols were approved by the Institutional Animal Ethics Committee (IAEC) of 
GITAM Institute of Pharmacy, Visakhapatnam, Andhra Pradesh, India(Registration No.1287/ac/09/CPCSEA and Protocol No: IAEC/GIP-1287/Bpharm/IP/ SM-NS/11/2012-13). Experiments were performed according to the guide for the care and use of laboratory animals.

\section{Acute toxicity study}

The acute toxicity studies were conducted over Swiss albino mice as per OECD guidelines $423,{ }^{23}$ where the limit test dose of $2000 \mathrm{mg} / \mathrm{kg}$, p.o., was used. Observations were made and recorded continuously for the first $4 \mathrm{~h}$ for any behavioural changes. They were then kept under observation up to 14 days after drug administration to find out the mortality if any. One-tenth of the maximum tolerated dose of ELEHR $(200 \mathrm{mg} / \mathrm{kg}$, body weight, p.o.) was selected for dead space wound model study.

\section{Sub-acute toxicity studies}

Sub-acute toxicity studies were done according to OECD guidelines $407,{ }^{24}$ with slight modifications. ${ }^{25}$ Wistar albino rats were randomly assigned into two groups ( $n=6 /$ group) where group I received distilled water ( $3 \mathrm{~mL} / \mathrm{kg}$, p.o.) which serves as the normal control and group II received ELEHR at a dose level $(200 \mathrm{mg} / \mathrm{kg}$, p.o.). All rats were treated twice daily for 14 days and were observed daily for physiological and behavioural changes. Body weight, food intake and water intake were monitored. Animals were also closely observed for signs of abnormalities during the whole treatment process. On $15^{\text {th }}$ day, the animals were anesthetized with pentobarbital sodium $0.035 \mathrm{gm} / \mathrm{kg}$, i.p. and blood samples were collected by retro-orbital puncture using capillary tubes for hematological and biochemical studies. Ethylenedi-aminetetraacetic acid (EDTA) was added to the blood samples collected for haematological analysis, whereas the blood samples for biochemical analysis was without EDTA. The hematological and biochemical parameters were co-related with the normal range of clinical laboratory parameters for Wistar albino rats. ${ }^{26}$

\section{Hematological analysis}

The blood samples collected in capillary tubes by retroorbital puncture from anesthetized Wistar rats and were used for the analysis of Hematological parameters like Platelet count, Haemoglobin ( $\mathrm{Hb})$ count, Red Blood Cell (RBC) count, White Blood Cell (WBC) count, Differential count (DC) (Neutrophils, Lymphocytes, Eosinophils, Monocytesand Basophils). ${ }^{27,28}$

\section{Biochemical analysis}

For biochemical analysis, blood were centrifuged at $3000 \times \mathrm{g}$ for $10 \mathrm{~min}$ at $4^{\circ} \mathrm{C}$. Serum was separated from the blood after centrifugation and stored at $-20^{\circ} \mathrm{C}$ until analysis. Biochemical parameters like aspartate transaminase (AST), alanine transaminase (ALT), ${ }^{29}$ alkaline phosphatase (ALP),$^{30}$ total bilirubin, ${ }^{31}$ total protein, ${ }^{32}$ albumin, ${ }^{33}$ serum creatinine, ${ }^{34}$ blood urea, ${ }^{35}$ total cholesterol, ${ }^{36}$ triglyceride $^{37}$ and glucose ${ }^{38}$ content were assayed using standard procedures.

\section{Evaluation of body weight and organ weight}

The evaluation of body weight of the control and treated animals were performed to check for possible toxicity. Macroscopic analysis of target organs of control and treated animals were done to evaluate any abnormalities in weight, texture and shape for determination of possible toxic effects. ${ }^{39}$ The major targeted organs include rat liver, pancreas and kidney.

\section{Histopathological studies}

Histopathological studies were performed on organ samples of liver, pancreas and kidney. After euthanasia, all animals were autopsied and the major organs like liver, pancreas and kidney were surgically taken out and were fixed in $20 \%$ formalin in normal saline. Sections of $5 \mu \mathrm{m}$ were obtained on a rotary microtome and then the material was stained by hematoxylin-eosin (HE). ${ }^{40}$ The sections were then analysed microscopically for pathological examinations.

\section{Evaluation of wound healing activity Experimental grouping and dosing}

The rats were acclimatised for one week prior to use in the experimental models. The selected animals were subdivided into three groups of six animals each $(n=6$ per group) for evaluating healing potential on excision, incision, and burn wound models. Group I: treated with simple ointment I.P. (vehicle control), Group II: treated with reference standards. Group III: treated with test ointment which was prepared by $10 \% \mathrm{w} / \mathrm{w}$ ELEHR in Simple ointment IP. Povidone iodine ointment $(5 \% \mathrm{w} / \mathrm{w})$ (Cipladine; mfg by: Jeps Pharmaceuticals, Sirmour-173025 (H.P.), Batch No: JMI 92) was used as the reference standard for excision and incision wound model, whereas silver sulfadiazine $(1 \% \mathrm{w} / \mathrm{w})$ was used as the reference standard for chemical and thermal burn injury model. For evaluating dead space wound model twelve animals were randomly divided into two groups of six animals each ( $\mathrm{n}=6 /$ group). Group I serve as control, which received only plain drinking water 
( $3 \mathrm{~mL} / \mathrm{kg}$, p.o.) and group II were separately administered with ELEHR at a dose of $200 \mathrm{mg} / \mathrm{kg}$ daily for 10 days.

\section{Excision wound model}

Wound healing activities were evaluated using Excision wound model on Wistar rats according to the methods described by Morton and Malone, 1972. ${ }^{41}$ Animals were anesthetized prior to creation of the wounds, with $1 \mathrm{~mL}$ of intravenous ketamine hydrochloride $(10 \mathrm{mg} / \mathrm{kg}$, body weight). An impression was made on the dorsal thoracic region $1 \mathrm{~cm}$ away from vertebral column and $5 \mathrm{~cm}$ away from ear on the anaesthetized rat. The dorsal fur of the animals was shaved with an electric clipper and the anticipated area of the wound to be created was outlined on the back of the animals with methylene blue using a circular stainless steel stencil. A full thickness of the excision wound of circular area of $500 \mathrm{~mm}^{2}$ and $2 \mathrm{~mm}$ depth was created along the markings using toothed forceps, scalpel and pointed scissors. Haemostasis was achieved by blotting the wound with cotton swab soaked in normal saline. The entire wound was left open. All surgical procedures were performed under aseptic conditions. The wounds were left untreated for a period of $24 \mathrm{~h}$. The extracts and reference drugs were applied topically at the wound site twice a day. The wound closure rate was assessed by tracing the wound on $5^{\text {th }}, 10^{\text {th }}$ and $15^{\text {th }}$ post wounding days using transparent paper and a permanent marker. Changes in wound area were calculated, giving an indication of the rate of wound contraction. Wound area was measured by retracing the wound on a millimetre scale graph paper. The percentage of wound closure was calculated using the formula. ${ }^{42,43}$

$$
\% \text { wound closure }=\frac{\text { wound area on day } 0-}{\text { wound area on day } n}
$$

Where $\mathrm{n}=5^{\text {th }}, 10^{\text {th }}$ and $15^{\text {th }}$ post wounding days The period of epithelialisation was also calculated as the number of days required for falling of the dead tissue remnants without any residual raw wound.

\section{Histomorphological analysis of wound tissue from healed excised wound}

The cross-sectional full thickness skin specimens (Wound tissues) were cut on the $16^{\text {th }}$ day post wounding from all the groups to study the histo pathological changes. The tissue samples were then fixed in Bouin's solution and were dehydrated through increasing grades of ethanol and then embedded in paraffin wax. The tissues were then cut to $5 \mu \mathrm{m}$ sections with a rotary microtome, deparaffinised, mounted on clean glass slides and stained with haematoxylin and eosin (HE). The glass slides were then observed under the microscope for histo morphological changes. ${ }^{44,45}$

\section{Incision wound model}

Incision wound model was performed according to the methods described by Ehrlich and Hunt. ${ }^{46}$ The rats were anaesthetized with $1 \mathrm{~mL}$ of intravenous ketamine hydrochloride $(10 \mathrm{mg} / \mathrm{kg}$, body weight) prior to and during creation of the wounds. The dorsal fur of the animals was shaved with an electric clipper and a longitudinal para vertebral incision of $6 \mathrm{~cm}$ long was made through the skin and cutaneous tissue on the back. After the incision, the parted skin was sutured $1 \mathrm{~cm}$ apart using a surgical thread and curved needle. The wounds were left undressed. Extract was topically applied over the wound once a day. The sutures were removed on $8^{\text {th }}$ post wound day and the application of the extract to the wounds continued till $10^{\text {th }}$ post wounding day. The wound breaking strength was measured on the $10^{\text {th }}$ day evening after the last application.

\section{Determination of wound breaking strength}

The breaking strength of the wound on each animal was measured by the constant water flow method. ${ }^{47}$ The rats were anesthetized and secured to the operation table and a line was drawn $3 \mathrm{~mm}$ away from the edge of the wound on either side. Two forceps were firmly applied on to the line facing each other on opposite side of the incision wound. One of the forceps was fixed on stands, while the other was connected to a freely suspended lightweight polypropylene graduated container through a string run over to a pulley. Water was allowed to flow from the reservoir slowly and steadily into the container. A gradual increase in weight was transmitted to the wound site pulling apart the wound edges. As and when the wound just opened up, the water flow was arrested and the volume of water collected in the container (approximately equal to its weight) was noted. The readings were recorded for a given incision wound and the procedure was repeated on the wound on the contra lateral side. The average reading of the group was taken as an individual value of breaking strength. Mean value gives the breaking strength for a given group.

\section{Dead space wound model}

The rats were anaesthetized with $1 \mathrm{~mL}$ of intravenous ketamine hydrochloride $(10 \mathrm{mg} / \mathrm{kg}$, body weight) prior to and during creation of the wounds and $1 \mathrm{~cm}$ incision was made on dorso-lumber part of the back. Two pre-weighed sterilized polypropylene tube (2.5 length $\mathrm{x} 0.25 \mathrm{~cm}$ diameter) were placed in the dead space of 
lumbar region of rat on each side and wounds were closed with a suture material. On the $10^{\text {th }}$ post wounding day, the granulation tissue formed on the implanted tubes was carefully detached from surfaces of the tubes. The wet weight of the granulation tissue collected was noted. The tissue samples were dried at $60^{\circ} \mathrm{C}$ for $12 \mathrm{~h}$ and weighed to determine the dry granulation tissue weight. Connective tissue parameter such as hydroxyproline content in granulation tissue was also determined by standard methods. ${ }^{48}$ Part of the granulation tissue was collected in phosphate-buffered saline for the estimation of antioxidant enzymes superoxide dismutase (SOD) and catalase (CAT).

\section{Estimation of hydroxyproline}

On day 10, a piece of skin from the wound area was taken and analysed for hydroxyproline content. Hydroxyproline is a basic constituent of collagen. The tissue sample taken from the wound area was dried in hot air oven at $60^{\circ} \mathrm{C}$ for $12 \mathrm{~h}$ to get dry granulation tissue which were weighed and kept in glass stoppered test tubes. To each tube containing about $40 \mathrm{mg}$ dried granulation tissues,

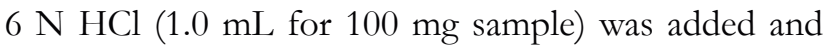
then kept on boiling water bath $\left(110^{\circ} \mathrm{C}\right)$ for $24 \mathrm{~h}(12 \mathrm{~h}$ each day for 2 days) for hydrolysis. The hydrolysate was then cooled and the excess acid was neutralized by $10 \mathrm{~N}$ $\mathrm{NaOH}$ using phenolphthalein as indicator. $1.0 \mathrm{~mL}$ of acid hydrolysate sample was mixed with $1 \mathrm{~mL}$ each of $0.01 \mathrm{M}$ copper sulfate solution, $2.5 \mathrm{~N}$ sodium hydroxide, and $6 \%$ hydrogen peroxide. The solution were mixed thoroughly and incubated for $5 \mathrm{~min}$ at $80^{\circ} \mathrm{C}$. After incubation period, the tubes are chilled in an ice water bath, and $4 \mathrm{~mL}$ of $3 \mathrm{~N}$ sulphuric acid were added with agitation followed by addition of $2 \mathrm{~mL}$ of $\mathrm{p}$-di-methyl amino benzaldehyde $(5 \%)$ solution and mixed thoroughly. Then the tubes were heated in a water bath for $15 \mathrm{~min}$ at $70^{\circ} \mathrm{C}$ and then cooled in an ice water bath. Then the absorbance was recorded at $540 \mathrm{~nm}^{49}$

\section{Estimation of granulation tissue antioxidants in wet tissue \\ Superoxide Dismutase (SOD)}

The inhibition of reduction of nitroblue tetrazolium (NBT) to blue colored formozan in presence of phenazine methosulphate (PMS) and Nicotinamide adenine dinucleotide (NADH) was measured at $560 \mathrm{~nm}$ using n-butanol as blank. $0.6 \mathrm{~mL}$ of $0.052 \mathrm{M}$ sodium pyrophosphate buffer ( $\mathrm{pH} 8.3$ ), $50 \mu \mathrm{L}$ of $186 \mu \mathrm{M}$ of PMS, $150 \mu \mathrm{L}$ of $300 \mu \mathrm{M} \mathrm{NBT}$, and $0.4 \mathrm{~mL}$ of distilled water was added to $0.2 \mathrm{~mL}$ of tissue homogenate. Reaction was initiated in the above by the addition of $0.1 \mathrm{~mL}$ of $780 \mu \mathrm{M} \mathrm{NADH}$ and incubated for $60 \mathrm{sec}$ at $30^{\circ} \mathrm{C}$. After incubation period, the reaction was stopped by the addition of $0.5 \mathrm{~mL}$ of glacial acetic acid. The reaction mixture was stirred vigorously and shaken with $2 \mathrm{~mL}$ of $n$-butanol. The mixture was allowed to stand for $10 \mathrm{~min}$, centrifuged at $3000 \mathrm{rpm}$ for $10 \mathrm{~min}$ and butanol layer was taken out. Colour intensity of the chromogen in the butanol was measured at $560 \mathrm{~nm}$ in spectrophotometer against n-butanol, a system devoid of enzyme that served as control. One unit of enzyme activity is defined as enzyme concentration required inhibiting the optical density at $560 \mathrm{~nm}$ of chromogen protection by $50 \%$ in one min under the assay conditions. The results were expressed as $\mathrm{IU} / \mathrm{mg}$ protein. ${ }^{50}$

\section{Catalase (CAT)}

The granulation tissue is homogenized (5\%) in $\mathrm{M} / 150$ phosphate buffer at $1-4^{\circ} \mathrm{C}$ and centrifuge at $1000 \mathrm{rpm}$ for 30 mins. The supernatant obtained from centrifugation was diluted $1: 10$ with water and $0.04 \mathrm{~mL}$ was taken for the assay. Decomposition of hydrogen peroxide in presence of catalase was followed at $240 \mathrm{~nm}$. The results were expressed in $\mathrm{nU} / \mathrm{mg}$ protein. ${ }^{51}$

\section{Chemical and thermal burn wound model}

The hairs of the dorsal skin were shaved mechanically $24 \mathrm{hrs}$ before induction ofburn. Then the animals were left for $24 \mathrm{hrs}$ for identifying any inflammation caused by shaving. Chemical burn injuries were induced in animals by spreading few drops of concentrated hydrochloric acid over the shaved skin on $7 \times 7 \mathrm{~cm}$ area. ${ }^{52}$ Thermal burn injuries were induced on dorsal skin of the rat by pressing of metal rod ( $2.5 \mathrm{~cm}$ diameter $)$ heated to $80-85^{\circ} \mathrm{C}$ for $20 \mathrm{sec}$. Then the wound area was dressed with sterile gauge and animals were housed separately after complete recovery from anaesthesia. Drugs were applied twice daily upon the burn. The wound closure rate was assessed on $5^{\text {th }}, 10^{\text {th }}, 12^{\text {th }}$ and $15^{\text {th }}$ post wounding days using transparent paper and a permanent marker. ${ }^{53}$ The percentage of wound healing was calculated for final analysis of results according to the following formula. ${ }^{42,43}$

$$
\% \text { wound closure }=\frac{\text { wound are on day } 0-}{\text { wound area on day } n} \times 100
$$

Where $\mathrm{n}=5^{\text {th }}, 10^{\text {th }}, 12^{\text {th }}$ and $15^{\text {th }}$ post wounding days

\section{Statistical analysis}

The data obtained in the studies were subjected to one way of analysis of variance (ANOVA) for determining the significant difference. The inter group significance was analyzed using Dunnet's t-test. A p-value 
$<0.05$ was considered to be significant. All the values were expressed as mean \pm SEM.

\section{RESULTS}

\section{Percentage yield and preliminary phytochemical analysis of ELEHR}

Ethanol extract of leaves of Hibiscus rosa-sinensis after complete drying yielded about $10.36 \%$ of extract. Preliminary phytochemical screening of ELEHR for detection of different secondary metabolites showed that the extract contains alkaloids, carbohydrates, sterols, flavonoids, saponins, tannins, andtriterpenoids (Table 1).

\section{In-vitro Antioxidant activity \\ DPPH radical scavenging activity}

The DPPH radical scavenging activity of ELEHR was estimated at different concentrations 200, 400, 600, 800 and $1000(\mu \mathrm{g} / \mathrm{mL})$. The result revealed that ELEHR was capable of neutralizing the DPPH free radicals via hydrogen donating activity in a dose dependant manner (Figure 1A). The maximum DPPH radical scavenging activity of ELEHR was recorded at a dose of $1000 \mu \mathrm{g} / \mathrm{mL}$ which was $91.15 \pm 1.32 \%$.

\section{Nitric oxide (NO) scavenging activity}

Estimation of Nitric oxide (NO) scavenging activity of ELEHR at doses of 200, 400, 600, 800 and $1000(\mu \mathrm{g} / \mathrm{mL})$ revealed that ELEHR effectively reduced the generation of NO(Figure 1B). Maximum Nitric oxide (NO) scavenging activity was observed at the dose of $1000 \mu \mathrm{g} / \mathrm{mL}$ which was $86.45 \pm 2.09 \%$.

\section{Superoxide radical scavenging activity}

The superoxide radical scavenging activity of ELEHR at doses of 200, 400, 600, 800 and $1000(\mu \mathrm{g} / \mathrm{mL})$ revealed that ELEHR was effective in scavenging superoxide anion in a dose dependant manner (Figure 1C). Maximum superoxide radical scavenging activity was observed at $1000 \mu \mathrm{g} / \mathrm{mL}$ dose of ELEHR which was $79.12 \pm 1.56 \%$.

\section{Acute toxicity studies}

No mortality or morbidity was observed in animals through the 14 day period following single oral administration. Morphological characteristics (fur, skin, eyes and nose) appeared normal. No salivation, diarrhoea, lethargy or unusual behaviours such as self mutilation, walking backward etc. were observed. Gait and posture, reactivity to handling or sensory stimuli, grip strength was all normal. Food and water intake showed daily fluctuations within the range of control animals. This indicates that the ethanolic extract from Hibiscus rosa-sinensis leaves was safe to a single dose of 2000 $\mathrm{mg} / \mathrm{kg}$, body weight. Hence $200 \mathrm{mg} / \mathrm{kg}$ oral doses of ELEHR were selected to evaluate wound healing activities.

\section{Sub-acute toxicity studies}

\section{General behaviour of the animals}

Over the 14 days of sub-acute toxicity study there was no significant change in body weight, since there was no significant difference between the results representing the control group and the test extract group. No mortalities were recorded in rats after 14 days of dosing of ELEHR (200 mg/kg, p.o.). None of the animals after administration of ELEHR (200 mg/kg, p.o.) showed any obvious morbidity or clinical symptoms of toxicity such as changes in the skin and fur, eyes, respiratory rate, autonomic (salivation, perspiration and pilo erection) and central nervous system (ptosis and drowsiness) effects throughout the experimental period of 14 days. The control group also showed no symptoms of toxicity.

\section{Effect on the haematological and biochemical blood parameters of the animals}

In the biochemical parameters evaluated, all parameters remained almost unchanged as non-significant variations were observed. All the values of the biochemical parameters for both the control and test groups fall within the normal range as shown in Table 2. The haematological parameters of rats treated with ELEHR $(200 \mathrm{mg} / \mathrm{kg}$, p.o.) showed almost an unchanged value with non-significant variations when compared with the control group. Further the haematological parameters of rats after treatment of control vehicle and ELEHR $(200 \mathrm{mg} / \mathrm{kg}$, p.o.) shows normal values as they fall within the normal range of haematological parameters of rats (Table 3).

\section{Effect on body weight and organ weight}

The body weight of rats treated with both control and ELEHR (200 mg/kg, p.o.) treated groups over 14 days period did not cause any significant change when compared with the control (Figure 2A). The organ weights of rats treated with ELEHR $(200 \mathrm{mg} / \mathrm{kg}$, p.o.) increased slightly for liver and pancreas whereas the kidney weight decreased slightly when compared with the control treated group (Figure 2B). The organs examined were liver, kidney and pancreas of rats.

\section{Histopathological studies}

Histopathological analysis of the liver, kidney and pancreas of rats were performed on the $15^{\text {th }}$ day after administration with control vehicle and ELEHR (200 $\mathrm{mg} / \mathrm{kg}$, p.o.). Multiple sections of the liver showed normal lobular architecture in control treated group. In extract treated group it was observed that the hepatocyte 
appeared nearly normal with almost no signs of specific lobular hepatitis when compared with the control treated group. There was also no evidence of bile stasis, granuloma, dysplasia or malignancy in both the groups (Figure 3: A and B). Similarly the multiple sections taken out from renal biopsy showed almost normal size and shape of glomeruli, tubules, intestinum and blood vesicles. There was no strong evidence of acute tubular necrosis and glomerular changes for the extract treated groups when compared to the observations of the control treated groups (Figure 3: C and D). Multiple sections of rat's pancreas showed normal architecture in control treated group, whereas in extract treated group almost negligible abnormalities were observed in the architecture of both pancreatic acini and islets (Figure 3: E and F).

\section{Wound healing activity}

\section{Effect of ELEHR on healing of Excision wound}

The result showed that the percentage wound closure rate increased significantly $(\mathrm{P}<0.01)$ for reference standard Povidone iodine $(5 \% \mathrm{w} / \mathrm{w})$ as well as ELEHR $(10 \% \mathrm{w} / \mathrm{w})$ during the 15 days study. Maximum wound closure rate was observed in the $15^{\text {th }}$ day where the percentage wound closure in reference standard Povidone iodine $(5 \% \mathrm{w} / \mathrm{w})$ and ELEHR $(10 \% \mathrm{w} / \mathrm{w})$ was $97.23 \pm$ 1.62 and $96.41 \pm 2.07$ respectively. Average number of days that took for the shedding of eschar without leaving any residual raw wound (epithelisation period) of reference standard Povidone iodine $(5 \% \mathrm{w} / \mathrm{w})$ and ELEHR $(10 \% \mathrm{w} / \mathrm{w})$ was $16.63 \pm 0.09$ and $17.04 \pm 0.61$ respectively. Thus ELEHR $(10 \% \mathrm{w} / \mathrm{w})$ showed a time dependant healing effect on wound surface area in excision wound in rats (Figure 4).

Histological studies of excision biopsy of skin at day 15 showed almost healed skin structures with normal epithelisation, restoration of adnexa, and fibrosis within the dermis in both reference standard Povidone iodine $(5 \% \mathrm{w} / \mathrm{w})$ and ELEHR $(10 \% \mathrm{w} / \mathrm{w})$ treated groups when compared to control group (Figure 5).

\section{Effect of ELEHR on healing of incision wound}

In the Incision wound model the result revealed that wound breaking strength on $10^{\text {th }}$ post wound day increased significantly $(\mathrm{P}<0.01)$ when compared with the control group(Figure 6 ). The wound breaking strength for reference standard Povidone iodine $(5 \% \mathrm{w} / \mathrm{w})$ and ELEHR $(10 \% \mathrm{w} / \mathrm{w})$ was $385.03 \pm 4.91$ and $338.82 \pm$ 6.91 respectively, whereas the breaking strength for control group was $108.26 \pm 8.28$. Thus the increase in wound breaking strength in extract treated group shows the healing effect of ELEHR in incision wounds.

\section{Effect of ELEHR on healing of dead space wound}

In dead space wound model the weight of dry and wet granulation tissue were significantly $(\mathrm{P}<0.01)$ increased in ELEHR treated group when compared with the control. Estimation of hydroxyproline content in the granulation tissue revealed that the animal groups treated with ELEHR (200 mg/kg, p.o.) increased significantly $(\mathrm{P}<0.01)$ when compared with control treated group. Estimation of granulation tissue antioxidant enzymes SOD and CAT revealed that ELEHR $(200 \mathrm{mg} / \mathrm{kg}$, p.o.) treated group significantly $(\mathrm{P}<0.05)$ increased the levels of antioxidant enzymes SOD and CAT (Table 4).

\section{Effect of ELEHR on healing of chemical and thermal burn wounds}

The contracting ability of wounds for both thermal and chemical induced burn wounds are depicted in Figure 7. The result shows that in both chemical and thermal induced burn wound there is a significant $(\mathrm{P}<0.01)$ increase in percentage wound closure in ELEHR $(10 \%$ $\mathrm{w} / \mathrm{w})$ and Silver Sulfadiazine $(1 \% \mathrm{w} / \mathrm{w})$ treated groups when compared with control group. In both chemically and thermally induced burn injury model the percentage wound closure increased with increase in number of days. In thermal induced burn model the maximum wound closure was observed on the $15^{\text {th }}$ day of study where it was observed that there was complete wound closure rate in ELEHR $(10 \% \mathrm{w} / \mathrm{w})$ treated group, whereas for chemical induced burn wound model the maximum wound closure was observed on the $15^{\text {th }}$ day where it was $96.6 \pm 3.1 \%$ in ELEHR $(10 \% \mathrm{w} / \mathrm{w})$ treated group. In thermal induced burn wound the period of epithelisation was recorded for both silver sulfadiazine $(1 \% \mathrm{w} / \mathrm{w})$ and ELEHR $(10 \% \mathrm{w} / \mathrm{w})$ treated groups which was $17.23 \pm 0.81$ and $18.09 \pm 1.6$ respectively, whereas in chemical induced burn injury the period of epithelisation was $18.1 \pm 1.03$ and $17.1 \pm 1.03$ for silver sulfadiazine $(1 \% \mathrm{w} / \mathrm{w})$ and ELEHR $(10 \% \mathrm{w} / \mathrm{w})$ treated groups respectively.

\section{DISCUSSION}

In many countries herbal medicines and its derivatives have been used as an alternative to allopathic medicines in treatment of various diseases. Despite the widespread use of herbal medicine for treating various diseases there has been very few scientific studies conducted on herbals to provide knowledge about their efficacy and safety. ${ }^{54}$ Acute toxicity is an initial study on the safety assessment of the drug and also provides us the basis for classification and labelling. It also provides initial information about the mode of toxic action of a substance by which we can fix a dose of a new compound 


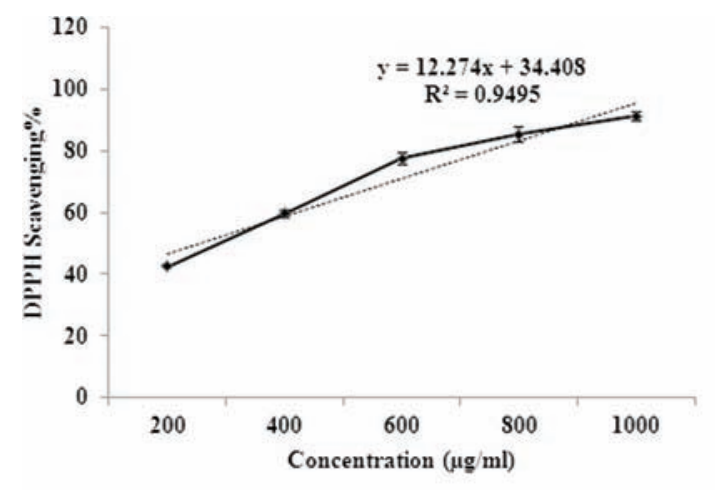

(A)

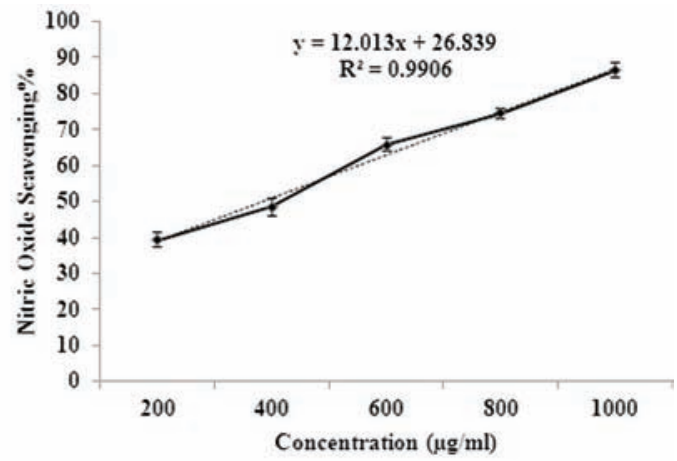

(B)

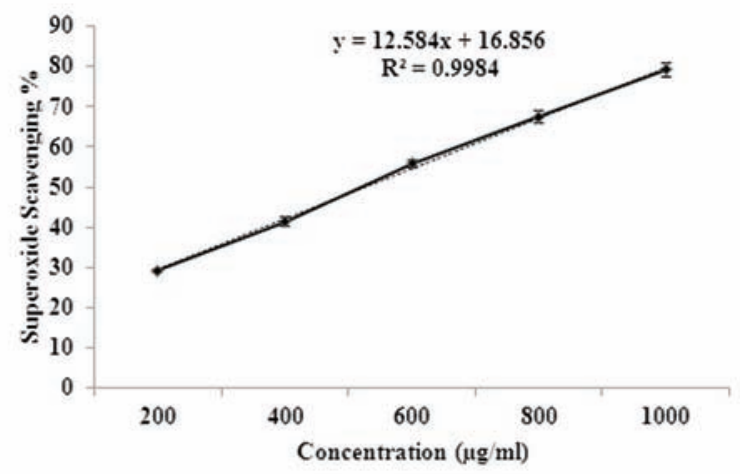

(C)

Figure 1: (A) Dose response curve for percentage scavenging of DPPH by ELEHR.

(B) Dose response curve for percentage scavenging of Nitric oxide by ELEHR.

(C) Dose response curve for percentage scavenging of Superoxide by ELEHR.

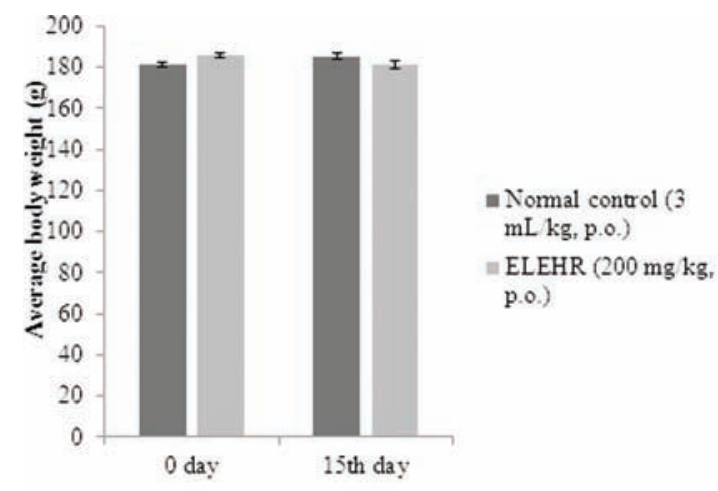

(A)

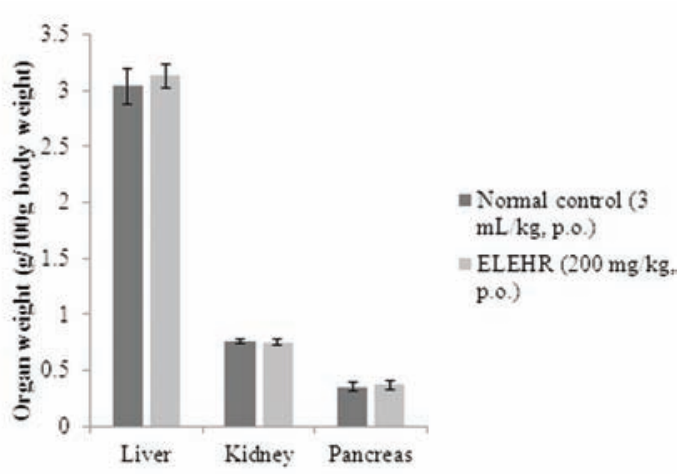

(B)

Figure 2: (A) Effects on body weight of rats after treatment with ELEHR.

(B) Effects on organ weights in rats after oral administration of ELEHR. 


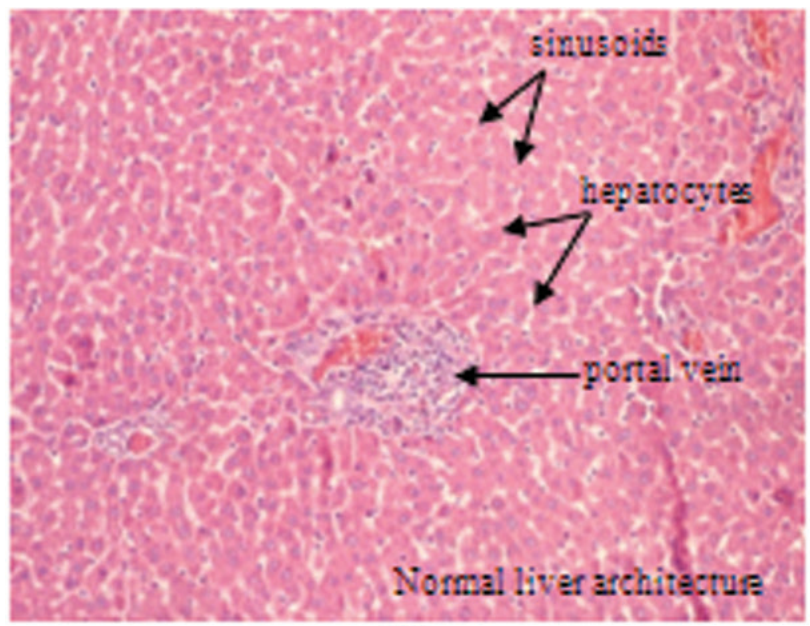

(A)

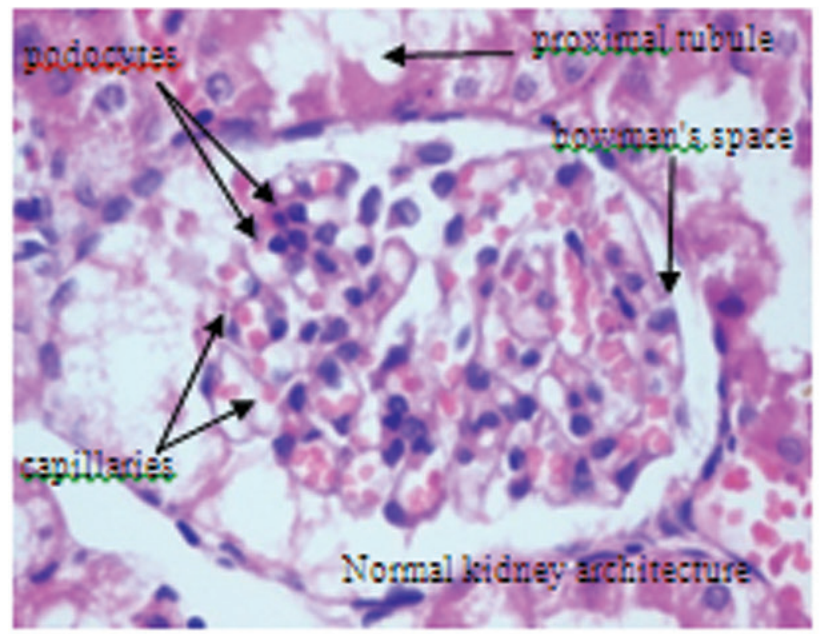

(C)

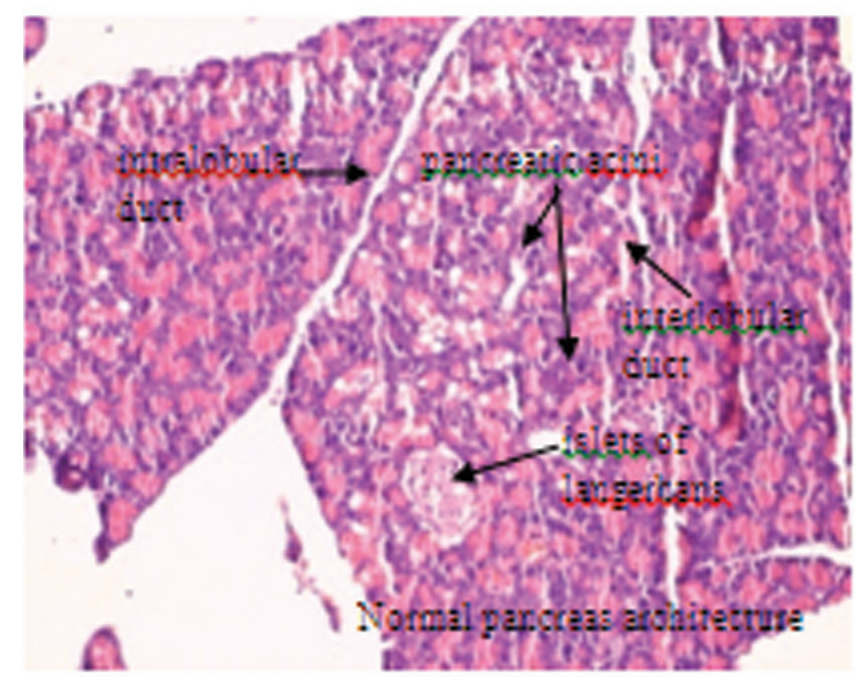

(E)

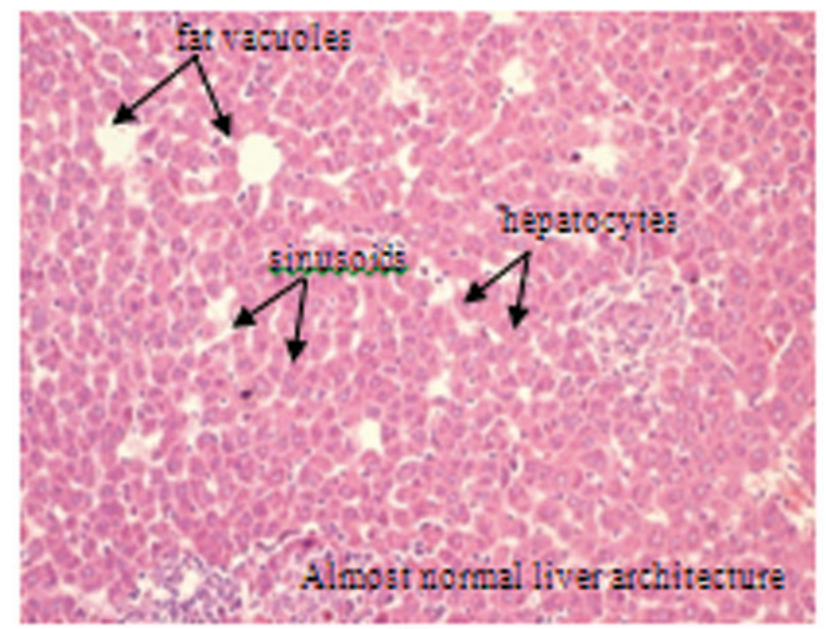

(B)

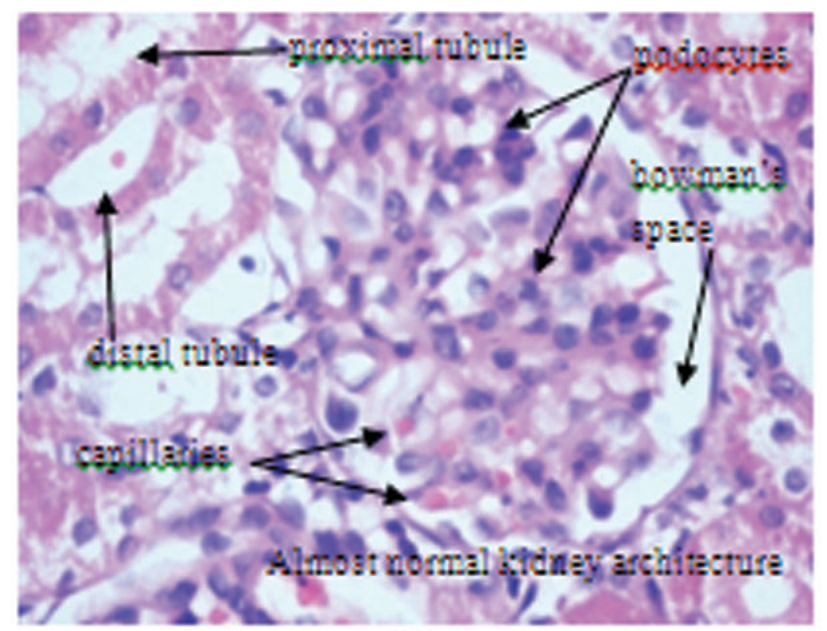

(D)

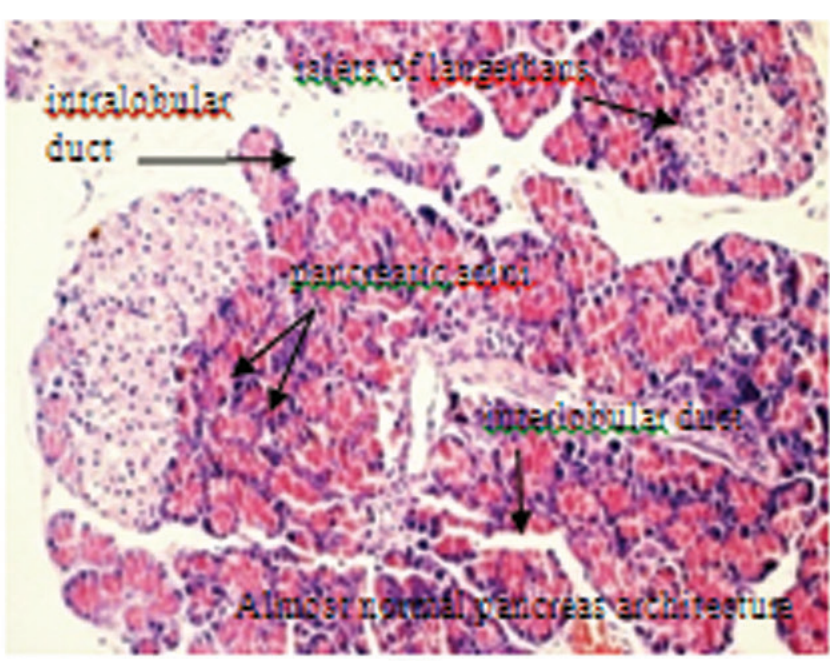

(F)

Figure 3: Photomicrographs of liver, kidney and Pancreas histopathology (A) Section of rat liver showing normal architecture for normal control group. (B) Section of rat liver treated with ELEHR (200 mg/kg, p.o.). (C) Section of rat kidney showing normal architecture for normal control group. (D) Section of rat kidney treated with ELEHR (200 mg/kg, p.o.). (E) Section of rat pancreas showing normal architecture for normal control group. (F) Section of rat pancreas treated with ELEHR (200 mg/kg, p.o.). 


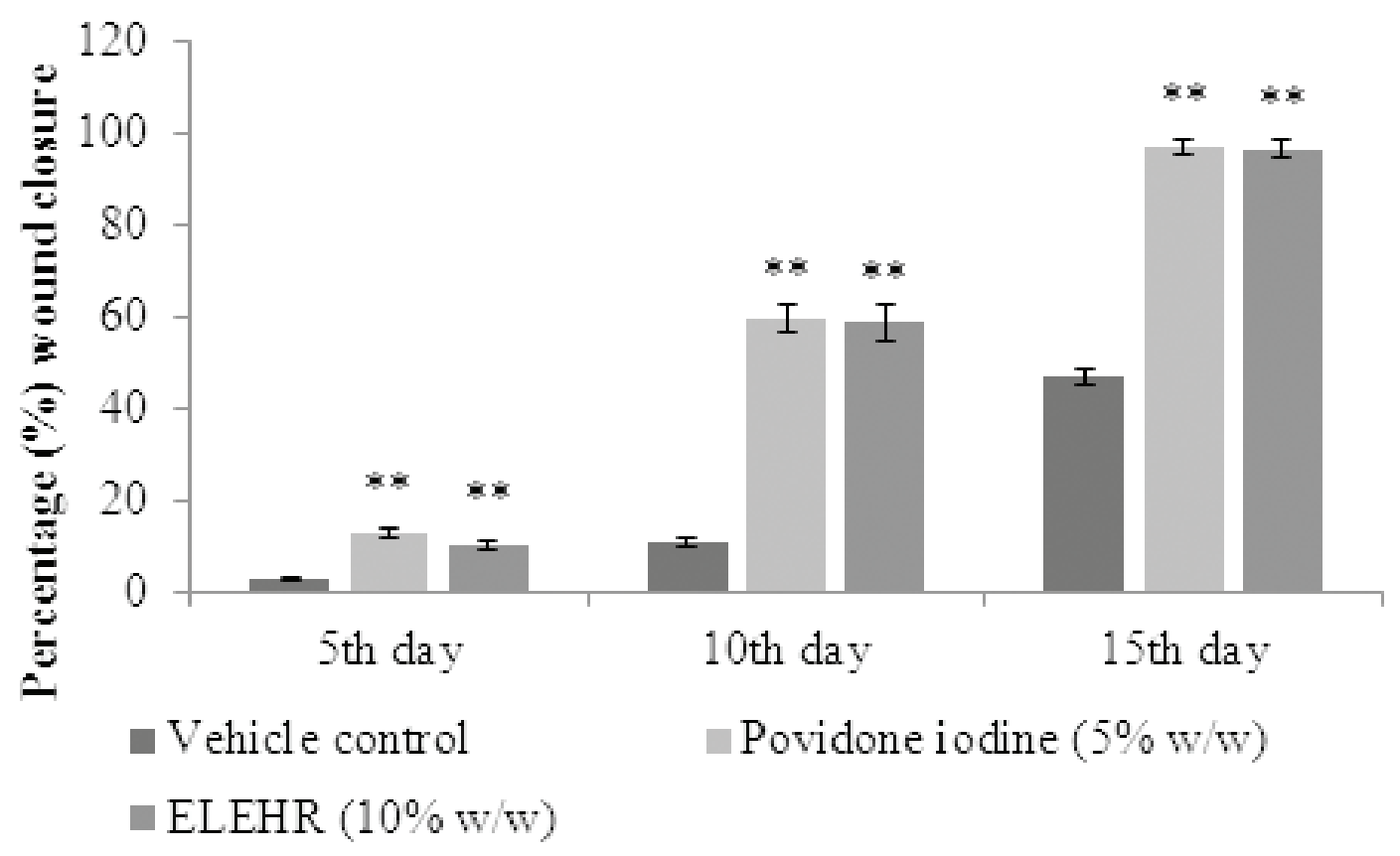

Figure 4: Percentage wound contraction of ELEHR in Excision Wound Model. Values are expressed as mean \pm S.E. ( $n=6)$. Statistical analysis done by one way ANOVA followed by Dunnet $s$ t-test. ${ }^{* *} \mathrm{P}<0.01$ compared to control group.

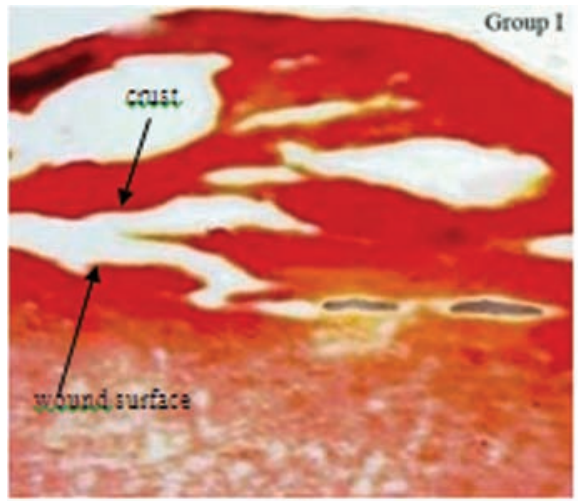

(A)

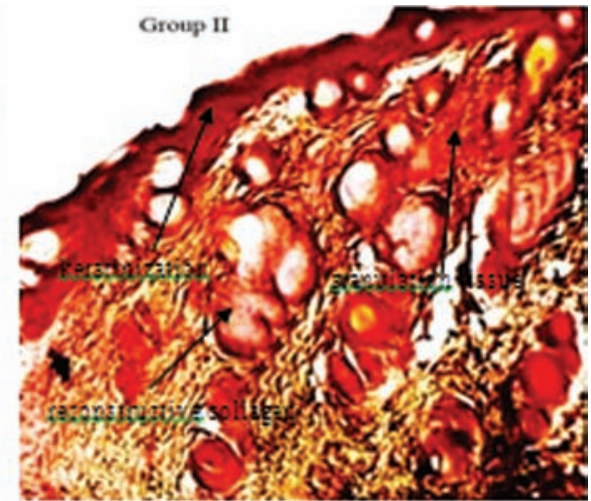

(B)

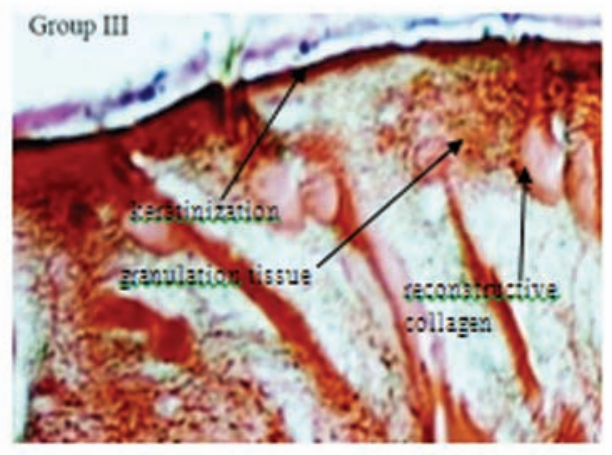

(C)

Figure 5: (A) Group I: (control-treated with simple ointment) showing with less collagen and more macrophages with evidence of chronic inflammation. (B) Group II: (standard-treated with povidone-iodine) Granulation tissue formation, showing significant collagenation, lesser fibroblasts and capillaries, and re-epithelialization, with reduced pus cells. (C) Group III: (treated with $10 \%$ w/w ELEHR) showing significant increased collagenation, few macrophages and capillaries, appreciable angiogenesis and granulation tissue formation. Evidence of hair follicle and re-epithelialization. 


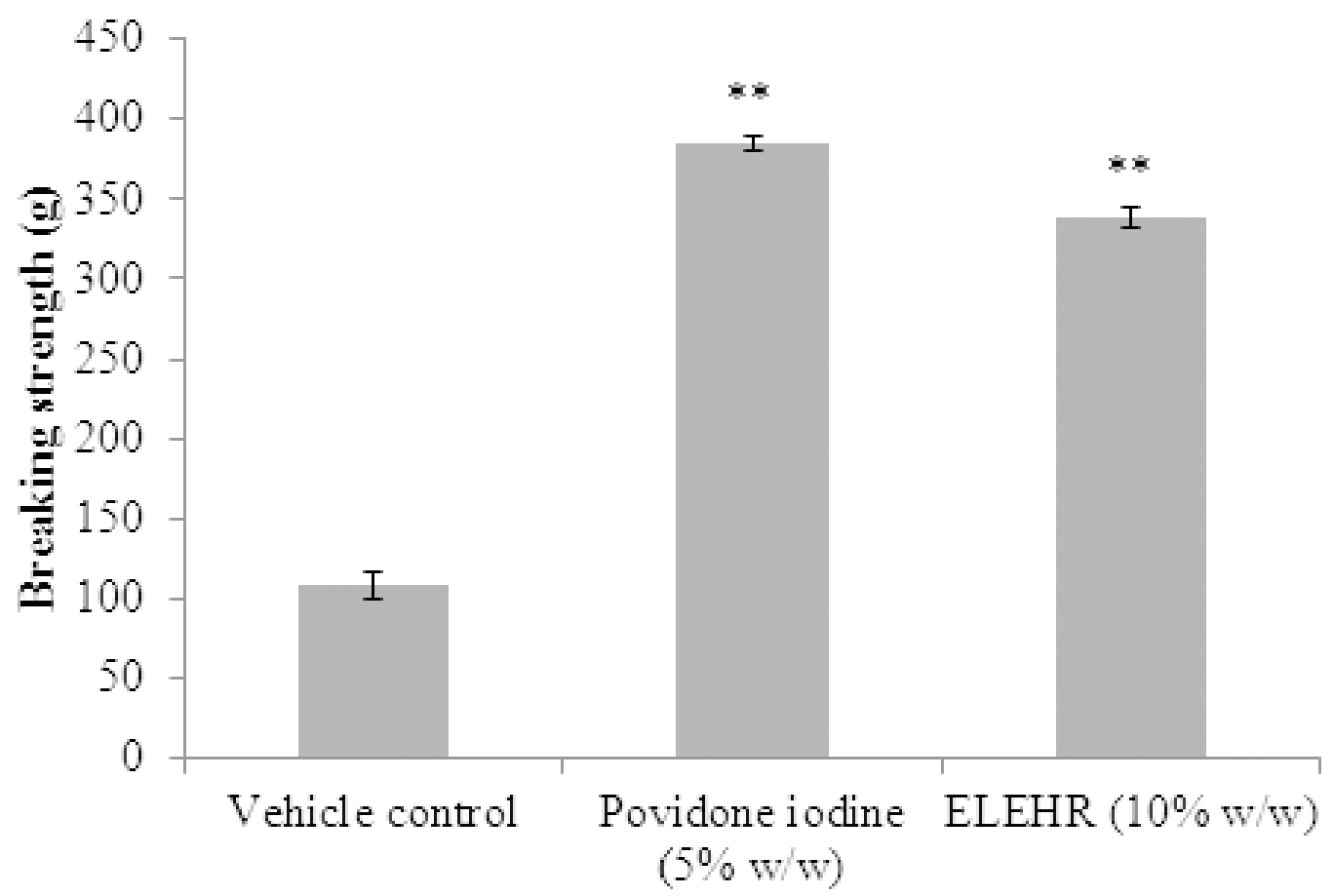

Figure 6: Effect of ELEHR on wound breaking strength (Incision Wound Model). Values are expressed as mean \pm S.E. ( $n=6$ ). Statistical analysis done by one way ANOVA followed by Dunnet $s$ t-test. ${ }^{\star \star} \mathrm{P}<0.01$ compared to control group.

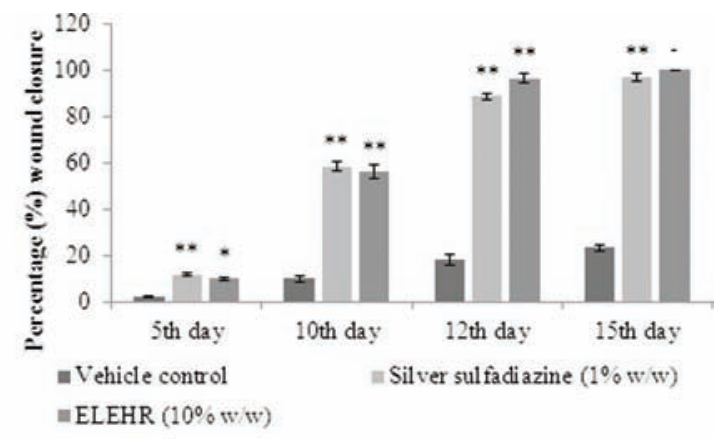

(A)

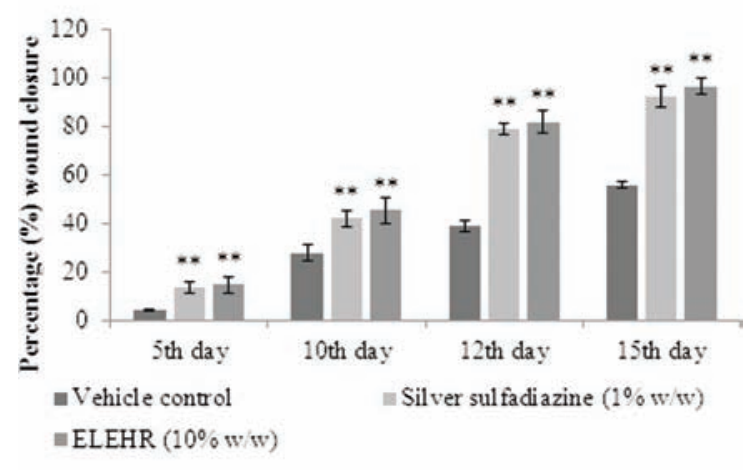

(B)

Figure 7: (A) Percentage wound contraction on thermal burn injuries in rats.

(B) Percentage wound contraction on chemical burn injuries in rats. Values are expressed as mean $\pm S$.E. $(n=6)$. Statistical analysis done by one way ANOVA followed by Dunnet $s$ t-test. ${ }^{*} \mathrm{P}<0.05$, ${ }^{* *} \mathrm{P}<0.01$ compared to control group. 


\section{Table 1: Preliminary phytochemical screening of ethanolic leaves extract of Hibiscus rosa-sinensis L. (ELEHR)}

\begin{tabular}{|c|c|c|}
\hline SI no. & Phytochemical constituents & Inference \\
\hline 1 & Alkaloids & + \\
\hline 2 & Flavonoids & + \\
\hline 3 & Triterpenoids & + \\
\hline 4 & Saponins & + \\
\hline 5 & Tannins & + \\
\hline 6 & Proteins and amino acids & + \\
\hline 7 & Carbohydrates & + \\
\hline 8 & Sterols & - \\
\hline 9 & Gums and mucilages \\
\hline (+) Present, (-) Absent
\end{tabular}

\section{Table 2: Effects of ELEHR on biochemical parameters in male Wistar rats}

\begin{tabular}{|c|c|c|c|c|}
\hline Parameter & Unit & $\begin{array}{l}\text { Normal control } \\
\text { (3 mL/kg, p.o.) }\end{array}$ & $\begin{array}{c}\text { ELEHR } \\
\text { (200 } \mathrm{mg} / \mathrm{kg}, \text { p.o.) }\end{array}$ & Normal Range $^{26}$ \\
\hline Total bilirubin & $\mathrm{mg} / \mathrm{dL}$ & $0.11 \pm 0.02$ & $0.10 \pm 0.03$ & $0.05-0.15$ \\
\hline Total protein & $\mathrm{g} / \mathrm{dL}$ & $6.2 \pm 0.9$ & $7.1 \pm 0.8$ & $5.2-7.1$ \\
\hline Albumin & $g / d L$ & $4.1 \pm 0.9$ & $4.6 \pm 0.7$ & $3.4-4.8$ \\
\hline ALT & IU/L & $25.6 \pm 3.01$ & $23.1 \pm 3.02$ & $18-45$ \\
\hline AST & IU/L & $78.6 \pm 3.85$ & $81.8 \pm 2.5$ & $74-143$ \\
\hline ALP & IU/L & $65.8 \pm 4.3$ & $72.3 \pm 3.3$ & $62-230$ \\
\hline Creatinine & $\mathrm{mg} / \mathrm{dL}$ & $0.41 \pm 0.02$ & $0.29 \pm 0.03$ & $0.2-0.5$ \\
\hline Urea & $\mathrm{mg} / \mathrm{dL}$ & $20.8 \pm 1.91$ & $21.5 \pm 2.02$ & $12.3-24.6$ \\
\hline Total cholesterol & $\mathrm{mg} / \mathrm{dL}$ & $40.2 \pm 2.09$ & $42.3 \pm 4.8$ & $37-85$ \\
\hline Triglyceride & $\mathrm{mg} / \mathrm{dL}$ & $23.6 \pm 1.7$ & $22.1 \pm 1.8$ & $20-114$ \\
\hline Glucose & $\mathrm{mg} / \mathrm{dL}$ & $105.3 \pm 2.3$ & $121.2 \pm 3.1$ & $70-208$ \\
\hline
\end{tabular}

\section{Table 3: Effects of ELEHR on hematological parameters in male Wistar rats}

\begin{tabular}{|c|c|c|c|c|}
\hline Parameter & Unit & $\begin{array}{l}\text { Normal control } \\
\text { (3 mL/kg, p.o.) }\end{array}$ & $\begin{array}{c}\text { ELEHR } \\
\text { (200 } \mathrm{mg} / \mathrm{kg}, \text { p.o.) }\end{array}$ & Normal Range $^{26}$ \\
\hline Platelet & $10^{3} / \mu \mathrm{L}$ & $896 \pm 22.03$ & $958 \pm 23.6$ & 638-1177 \\
\hline Hemoglobin & $\mathrm{g} / \mathrm{dL}$ & $14.8 \pm 0.2$ & $15.3 \pm 0.3$ & 13.7-17.6 \\
\hline Red Blood Cell & $10^{6} / \mu \mathrm{L}$ & $8.23 \pm 0.5$ & $8.6 \pm 0.1$ & $7.27-9.65$ \\
\hline White Blood Cell & $10^{3} / \mu \mathrm{L}$ & $6.1 \pm 0.5$ & $7.3 \pm 0.5$ & $1.96-8.25$ \\
\hline Neutrophils & $10^{3} / \mu \mathrm{L}$ & $0.71 \pm 0.03$ & $0.83 \pm 0.02$ & $0.22-1.57$ \\
\hline Lymphocytes & $10^{3} / \mu \mathrm{L}$ & $4.33 \pm 0.7$ & $4.11 \pm 0.8$ & $1.41-7.11$ \\
\hline Eosinophils & $10^{3} / \mu \mathrm{L}$ & $0.06 \pm 0.01$ & $0.07 \pm 0.01$ & $0.01-0.16$ \\
\hline Monocytes & $10^{3} / \mu \mathrm{L}$ & $0.08 \pm 0.01$ & $0.07 \pm 0.01$ & $0.03-0.18$ \\
\hline Basophils & $10^{3} / \mu \mathrm{L}$ & 00 & 0.00 & $0.0-0.05$ \\
\hline
\end{tabular}




\begin{tabular}{|c|c|c|c|c|c|}
\hline Treatment & $\begin{array}{l}\text { Wet weight of } \\
\text { granulation tissue } \\
(\mathrm{mg} / 100 \mathrm{~g})\end{array}$ & $\begin{array}{l}\text { Dry weight of } \\
\text { granulation tissue } \\
(\mathrm{mg} / 100 \mathrm{~g})\end{array}$ & $\begin{array}{l}\text { Concentration of } \\
\text { hydroxyproline } \\
\text { (mg/g tissue) }\end{array}$ & $\begin{array}{l}\text { Superoxide } \\
\text { dismutase (IUI } \\
\text { mg protein) }\end{array}$ & $\begin{array}{l}\text { Catalase (IU/ } \\
\text { mg protein) }\end{array}$ \\
\hline Vehicle control & $88.66 \pm 3.07$ & $41.05 \pm 2.33$ & $28.5 \pm 4.02$ & $0.105 \pm 0.05$ & $0.11 \pm 0.02$ \\
\hline ELEHR (200 mg/kg, p.o.) & $108.6 \pm 5.08^{\star \star}$ & $68.2 \pm 3.9^{\star \star}$ & $60.66 \pm 4.67^{\star \star}$ & $0.148 \pm 0.03^{\star}$ & $0.51 \pm 0.02^{*}$ \\
\hline
\end{tabular}

Values are expressed as mean \pm S.E. $(n=6)$. Statistical analysis done by one way ANOVA followed by Dunnet's t-test. ${ }^{*}<<0.05, * * P<0.01$ compared to control group.

and help in dose determination in animal studies. ${ }^{55}$ In our study a single administration of ELEHR with increasing doses did not produce any abnormities in acute toxicity. Sub-acute ingestion of ELEHR produced behavioural change of very low intensity. The body weight and organ weight shows very little change when compared with the control. Thus ELEHR does not alter much of the behavioural and general morphological changes. The haematopoietic system is considered one of the most sensitive targets for toxic compounds and an important index of physiological and pathological status in man and animal. ${ }^{56}$ The haematological profile of rats after treatment with extracts showed values which falls within the normal range values of clinical laboratory parameters. Biochemical parameters were also studied and they showed very little variation when compared with the control and they also fall within the normal range of biochemical parameters of rats. This indicates that the sub-acute administration of ELEHR is not able to produce toxic effects on the haematological and biochemical profile of rats.

The DPPH scavenging activity is based on the scavenging of $\mathrm{DPPH}$ by the addition of an antioxidant or radical species that decolourizes the DPPH solution. The degree of change in colour is proportional to the concentration and potency of the antioxidants. Decrease in absorbance of the reaction mixture points out the free radical scavenging activity of the test compound. ${ }^{57}$ The result of the DPPH scavenging activity showed strong antioxidant activity of the plant extract in a dose dependant manner. Thus ELEHR contain phytochemical constituents that were able to donate hydrogen to a free radical to scavenge the potential damage.

The superoxide radical is considered a major biological source of reactive oxygen species (ROS).$^{58}$ superoxide anion is a weak oxidant and gives rise to strong and dangerous hydroxyl radicals as well as singlet oxygen, both of which are responsible for causing oxidative stress. ${ }^{59}$ The result of our study showed that the plant extract had sufficient capacity of scavenging superoxide radical in a dose dependant manner. Thus ELEHR possesses powerful antioxidant properties.
The Nitric oxide radical $\left(\mathrm{NO}^{\circ}\right)$ is produced in biological tissues by specific nitric oxide synthesis. In the synthesis process, arginine is metabolized to citrulline with the production of nitric oxide radical $\left(\mathrm{NO}^{\circ}\right)$ via five electron oxidative reaction. At a $\mathrm{pH}$ of 7.2 sodium nitro prusside decomposes in aqueous solution and produce nitric oxide radical $\left(\mathrm{NO}^{*}\right)$. Stable products like nitrate and nitrite are produced when nitric oxide radical (NO') reacts with oxygen under aerobic conditions. The quantities of these stable products (nitrate and nitrite) are determined by the help of Griess reagent. ${ }^{60}$ In our study dose dependant nitric oxide radical scavenging activity was observed.

The wound healing process is a dynamic one which can be divided into three phases like inflammatory phase, Proliferation phase, and Maturation phase. The inflammatory phase is the body's natural response to injury. After initial wounding, the blood vessels in the wound bed contract and a clot is formed. Once haemostasis has been achieved, blood vessels then dilate to allow essential cells; antibodies, white blood cells, growth factors, enzymes and nutrients to reach the wounded area. This leads to a rise in exudate levels so the surrounding skin needs to be monitored for signs of maceration. It is at this stage that the characteristic signs of inflammation can be seen; erythema, heat, oedema, pain and functional disturbances. During proliferation, the wound is rebuilt with new granulation tissue which is comprised of collagen and extracellular matrix and into which a new network of blood vessels develop, a process known as angiogenesis. Healthy granulation tissue is dependent upon the fibroblast receiving sufficient levels of oxygen and nutrients supplied by the blood vessels. Healthy granulation tissue is granular and uneven in texture; it does not bleed easily and is pink or red in colour. The colour and condition of the granulation tissue is often an indicator of how the wound is healing. Dark granulation tissue can be indicative of poor perfusion, ischaemia and / or infection. Epithelial cells finally resurface the wound, a process known as epithelialisation. Maturation is the final phase and occurs once the wound has closed. This phase involves remodelling of collagen. In this study four different models were used to evaluate 
the effect of ELEHR on various phases of wound healing. ${ }^{61}$

In excision wound, ELEHR and standard (Povidone iodine) treated groups showed enhanced wound closure rate and epithelisation period than the control group. Histology of the skin area of excised wound on $15^{\text {th }}$ day post wounding showed normal epithelization, restoration of adnexa and fibrosis within the dermis in both ELEHR and standard (Povidone iodine) treated groups. Wound contraction is the process of mobilizing the healthy skin around the wound to cover the denuded area. It usually involves complex and superbly orchestrated interaction of cells, extracellular matrix, and cytokines. The activities of myofibroblast may be responsible for this centripetal movement of the wound margin. ${ }^{62}$ The wound contraction rate which was enhanced by ELEHR treatment was may be due to enhanced contractile property of myofibroblast or increased the number of myofibroblast entered the wound area. In incision wound, ELEHR showed an increase in wound breaking strength compared to control which may be due to the increase in collagen concentration and stabilization of the fibres. ${ }^{63}$

Collagen is a constituent of growing cell in healing tissue which can be estimated by monitoring the content of hydroxyproline. Thus higher the concentration of hydroxyproline higher would be the rate of wound healing. The biochemical data of dead space wound study showed an increase in granulation tissue weight and hydroxyproline content in extract treated group compared to control group. The increased hydroxyproline content in dead space wounds indicates faster collagen turnover which leads to rapid healing with concurrent increase in the breaking strength of the treated wounds and thus also indicating stabilization of collagen fibres. ${ }^{64}$ Oxidative stress is caused by overproduction of reactive oxygen species (ROS), thereby causing delay in the wound healing process. Therefore, in healing of chronic wounds elimination of ROS could be an important strategy and estimation of antioxidants like superoxide dismutase (SOD), catalase (CAT) etc., in granulation tissue becomes relevant as they help destroy free radicals and hasten the process of wound healing. ${ }^{65,66}$ In our study ELEHR treated groups showed potent in-vivo antioxidant activity by reducing free radicals stress and thus ELEHR could help to prevent oxidative damage and promote the healing process.

In burn wounds, the repair process is more complicated as there is an extensive loss of cells and tissues compared to an incision wound. A burn injury causes an alternation in the skin by producing a lesion in the corneal strata which is sufficient to cause the skin to lose its capacity to act as a barrier. ${ }^{52}$ The result of our study showed that erythema, thickness and inflammation were recorded in the control group animals, whereas these observations were lower in animals treated with silver sulfadiazine and ELEHR treated groups. Thus ELEHR was effective in contraction of burn wounds which may be due to the enhanced growth of keratinocytes and fibroblast. ${ }^{67}$ Various phyto constituents were reported from the leaves of Hibiscus rosa-sinensiswhich may be responsible for the strong wound healing properties such as $\beta$-sitosterol which was reported from the leaves possesses strong epithelisation activity. ${ }^{68}$

\section{CONCLUSION}

The present study demonstrated that ethanolic leaves extract of Hibiscus rosa-sinensis L. (ELEHR) possesses strong antioxidant activity in a dose dependant manner in all three in-vitro models; DPPH radical scavenging activity, Nitric oxide (NO) scavenging activity, and superoxide radical scavenging activity. Acute and Subacute toxicity study conducted on this plant showed that it has minimal amount of toxic effect on animals. ELEHR also showed strong wound healing activity which was evident by enhanced wound contraction rate and epithelisation period in excision and burn wound model. Wound breaking strength were also increased in ELEHR treated groups in incision wound model, whereas enhanced antioxidant and hydroxyproline content in dead space wound study indicates enhanced wound healing in ELEHR treated groups. Thus we can say that ethanolic leaves extract of Hibiscus rosa-sinensis $\mathrm{L}$. (ELEHR) possesses significant antioxidant and wound healing activity with a reasonable safety profile. Further investigations are required to identify the phyto-constituents which are responsible for the following activities and also study their mechanism of actions.

\section{ABBREVIATIONS}

$\begin{array}{cc}\text { ELEHR } & \text { Ethanolic leaves extract of Hibiscus rosa-sinensis L. } \\ \text { DPPH } & \text { 1,1-diphenyl-2- picrylhydrazyl } \\ \text { NO } & \text { Nitric oxide } \\ \text { PMS } & \text { Phenazine methosulphate } \\ \text { NADH } & \text { Nitroblue tetrazolium } \\ \text { NBT } & \text { Organization for Economic Community } \\ \text { OECD } & \text { Development } \\ \text { EDTA } & \text { Ethylene di-aminetetraacetic acid } \\ \text { Hb } & \text { Haemoglobin } \\ \text { RBC } & \text { Red Blood Cell } \\ \text { WBC } & \text { White Blood Cell }\end{array}$




$\begin{array}{cc}\text { DC } & \text { Differential Count } \\ \text { AST } & \text { Aspartate transaminase } \\ \text { ALT } & \text { Alanine transaminase } \\ \text { ALP } & \text { Alkaline phosphatase } \\ \mathrm{HE} & \text { Haematoxylin and Eosin } \\ \mathrm{SOD} & \text { Superoxide dismutase } \\ \mathrm{CAT} & \text { Catalase } \\ \mathrm{ROS} & \text { Reactive Oxygen Species } \\ \mathrm{HCl} & \text { Hydrochloric acid } \\ \mathrm{NaOH} & \text { Sodium hydroxide } \\ \mathrm{IU} & \text { International Unit }\end{array}$

\section{REFERENCES}

1. Vickers $A$, Zollman C. ABC of complementary medicine: herbal medicine. BMJ. 1999;319(7216):1050-3. http://dx.doi.org/10.1136/bmj.319.7216.1050; PMid:10521203 PMCid:PMC1116847

2. handel HS, Pathak A, Tailang M. Polyherbal formulations for anti diabetic therapy. Int J Pharm Pharm Sci. 2011;3(3):226-8.

3. Bajpai VK, Agrawal P. Studies on Phytochemicals, Antioxidant, Free Radical Scavenging and Lipid Peroxidation Inhibitory effects of Trachyspermum ammi seeds. Indian Journal of Pharmaceutical Education and Research. 2015;49(1):58-65. http://dx.doi.org/10.5530/ijper.49.1.8

4. Halliwell B, Gutteridge JMC. Formation of thiobarbituric acid reactive substances from deoxyribose in the presence of iron salts: the role of superoxide and hydroxyl radicals. FEBS Lett. 1981;128(2):347-52. http:// dx.doi.org/10.1016/0014-5793(81)80114-7

5. Rosidah YMF, Sadikun A, Ahmad M, Akowuah GA, Asmawi MZ. Toxicology evaluation of standardized methanol extract of Gynura procumbens. J Ethnopharmacol. 2009;123(2):244-9. http://dx.doi.org/10.1016/j.jep.2009. 03.011; PMid:19429368

6. Mohamed EAH, Lim CP, Ebrika OS, Asmawi MZ, Sadikun A, Yam MF. Toxicity evaluation of a standardised $50 \%$ ethanol extract of Orthosiphon stamineus.J Ethnopharmacol. 2011;133(2):358-63. http://dx.doi.org/10.1016/j. jep.2010.10.008; PMid:20937371

7. Adhirajan N, Kumar TR, Shanmugasundaram N, Babu M. In-vivo and in-vitro evaluation of hair growth potential of Hibiscus rosa-sinensis Linn. J Ethnopharmacol. 2003;88(2-3):235-9. http://dx.doi.org/10.1016/S03788741(03)00231-9

8. Nadkarni KM. Indian Materia Medica. $3^{\text {rd }}$ ed., Bombay, India: Popular book depot; 1954. PMid:13199797

9. Jadhav VM, Thorat RM, Kadam VJ, Sathe NS. Traditional medicinal uses of Hibiscus rosa-sinensis. J Pharm Res. 2009;2(8):1220-2.

10. Anonymous. The Wealth of India. Raw materials. vol. 5, New Delhi; CSIR;1959

11. Kumar A, Singh A. Review on Hibiscus rosa sinensis. International Journal of Research in Pharmaceutical and Biomedical Sciences. 2012;3(2):534-8.

12. Pekamwar SS, Kalyankar TM, Jadhav AC. Hibiscus rosa-sinensis: a review on ornamental plant. World Journal of Pharmacy and Pharmaceutical Sciences. 2013;2(6):4719-27.

13. Adiele LC, Adiele RC, Enye JC.Wound healing effect of methanolic leaf extract of Napoleona vogelii (Family: Lecythidaceae) in rats. Asian Pac J Trop Med. 2014;7(8):620-4. http://dx.doi.org/10.1016/S1995-7645(14)60104-8

14. Souba WW, Wilmore D. Diet and nutrition in case of the patient with surgery, Truma and sepsis. In: Shils M, Oslon J, Shike M, Ross AC, eds. Moderen Nutrition in Health and Disease. Baltimore: Williams and Wilkins; 1999:1589-618.

15. Shih MF, Cherng JY. Potential Applications of Euphorbia hirta in Pharmacology, Drug Discovery Research in Pharmacognosy, Prof. Omboon Vallisuta (Ed.), ISBN: 978-953-51-0213-7, InTech, 2012. Available from: http:// www.intechopen.com/books/drug-discovery-research-in-pharmacognosy/ potentialapplications-of-euphorbia-hirta-in-pharmacology

16. Somboonwong J, Kankaisre M, Tantisira B, Tantisira MH. Wound healing activities of different extracts of Centella asiatica in incision and burn wound models: an experimental animal study. BMC Complement Altern Med. 2012;12(1):103. http://dx.doi.org/10.1186/1472-6882-12-103; PMid:22817824 PMCid:PMC3492213

17. Harborne JB. Phytochemical Methods: A Guide to Modern techniques of Plant analysis. New York, Chapman and Hall; 1984(1-36):37-214. http:// dx.doi.org/10.1007/978-94-009-5570-7 ; PMCid:PMC1193218

18. Kokate CK. Practical Pharmacognosy. $4^{\text {th }}$ ed. Delhi, India: Vallabh Prakashan; 1994:107.

19. Shimada K, Fujikawa K, Yahara K, Nakamura T. Antioxidative properties of xanthin and autooxidation of soybean oil in cyclodextrin emulsion. J Agric Food Chem. 1992;40(6):945-8. http://dx.doi.org/10.1021/jf00018a005

20. Rai S, Wahile A, Mukherjee K, Saha BP, Mukherjee PK. Antioxidant activity of Nelumbo nucifera (sacred lotus) seeds.J Ethnopharmacol. 2006;104(3):322-7. http://dx.doi.org/10.1016/j.jep.2005.09.025 ; PMid:16239089

21. Liu F, Ooi VFC, Chang ST. Free radical scavenging activity of mushroom polysaccharide extracts. Life Sciences. 1997;60(10):763-71. http://dx.doi. org/10.1016/S0024-3205(97)00004-0

22. Gülçin I, U־guz MT, Oktay M, Beydemir S, Küfrevio־glu Öl. Antioxidant and antimicrobial activities of Teucrium polium L. Journal of Food Technology. 2003;1(1):9-17.

23. Anonymous. OECD Guidelines for the Testing of Chemicals, Revised Draft Guidelines 423: Acute Oral toxicity-Acute Toxic Class Method, Revised Document. Govt. of India: CPCSEA, Ministry of Social Justice and Empowerment; 2000.

24. OECD. Test No. 407: repeated Dose 28-day oral toxicity study in rodents. In: OECD Guidelines For the Testing of Chemicals, Section 4: Health Effects. OECD Publishing; 2008.

25. Okoye TC, Akah PA, Ezike AC, Okoye MO, Onyeto CA, Ndukwu F, et al. Evaluation of the acute and sub acute toxicity of Annona senegalensis root bark extracts.Asian Pac J Trop Med. 2012;5(4):277-82. http://dx.doi. org/10.1016/S1995-7645(12)60039-X

26. Giknis MLA, Clifford CB. Clinical laboratory parameters for $\mathrm{Crl}$ WI(Han); Charles River Laboratories; 2008.

27. Wintrobe MM, Lee GR, Boggs DR, Bithel TC, Athens JW, Foeresters J. Clinical Hematology, seventh ed. Philadelphia: Les and Febiger; 1976:961.

28. Jain NC. Sacham's Veterinary Hematology $4^{\text {th }}$ ed., Philadelphia: Lea and Febigir; 1986:600.

29. Reitman S, Frankel SA. Colourimetric method for the determination of serum oxaloacetatic and glutamic pyruvic transaminases.Am J Clin Pathol. 1957;28(1):56-63. http://dx.doi.org/10.1093/ajcp/28.1.56 ; PMid:13458125

30. Kind PR, King EJ. Estimation of plasma phosphatase by determination of hydrolysed phenol with antipyrine. J Clin Pathol. 1954;7(4):322-6. http:// dx.doi.org/10.1136/jcp.7.4.322

31. Malloy HT, Evelyn KA. The determination of bilirubin with the photometric colorimeter.J Biol Chem. 1937;119:481-90.

32. Lowry OH, Rosebrough NJ, Farr AL, Randal RJ. Protein measurement with the folin phenol reagent. J Biol Chem. 1951;193(1):265-75. PMid:14907713

33. Webster $\mathrm{D}$. The immediate reaction between bromocresol green and serum as a measure of albumin content. Clin Chem. 1977;23(4):663-5. PMid:844162

34. Slot C. Plasma creatinine determination. A new and specific Jaffe reaction method. Scand J Clin Lab Invest. 1965;17(4):381-7. http://dx.doi. org/10.3109/00365516509077065; PMid:5838275

35. Natelson S, Scott ML, Beffa C. A rapid method for the estimation of urea in biologic fluids. Am J Clin Pathol. 1951;21(3):275-81. PMid:14818981

36. Allain CC, Poon LS, Chan CSG, Richmond W, Fu PC. Enzymatic determination of total serum cholesterol. Clin Chem. 1974;20(4):470-5. PMid:4818200

37. Werner M, Gabrielson DG, Eastman J. Ultramicro determination of serum triglycerides by bioluminescent assay. Clin Chem. 1981;27(2):268-71. PMid:7460277

38. Trinder P. Determination of blood glucose using 4-amino phenazone as oxygen acceptor.J Clin Pathol. 1969;22(2):246. http://dx.doi.org/10.1136/ jcp.22.2.246-b ; PMid:5776563 PMCid:PMC474047

39. Dacie JV, Lewis SM. Practical haematology, 7th ed., London: Churchill Livingstone; 1991:160.

40. Luna LG. Manual of Histological Staining Methods of the Armed Forces Institute of Pathology. New York: Blakiston Division, McGraw Hill; 1968:258. 
41. Morton JP, Malone MH. Evaluation of vulnerary activity by an open wound procedure in rats. Arch Int Pharmacodyn Ther. 1972;196(1):117-26. PMid:5059357

42. Kokane D, More R, Kale M, Nehete M, Mehendale P, Gadgoli C. Evaluation of wound healing activity of root of Mimosa pudica. J Ethnopharmacol. 2009;124(2):311-5. http://dx.doi.org/10.1016/j.jep.2009.04.038; PMid:19397984

43. Suntar IP, Akkol EK, Yilmazer D, Baykal T, Kirmizibekmez H, Alper, M, et al. Investigations on the in vivo wound healing potential of Hypericum perforatum L. J Ethnopharmacol. 2010;127(2):468-77. http://dx.doi.org/10.1016/j. jep.2009.10.011; PMid:19833187

44. Umachigi SP, Jayaveera KN, Kumar ACK, Kumar GS, Swamy VBM, Kumar KDV. Studies on wound healing properties of Quercus infectoria. Trop J Pharm Res. 2008;7(1):913-9. http://dx.doi.org/10.4314/tjpr.v7i1.14677

45. Sheeba M, Emmanuel S, Revathi K, Ignacimuthu S. Wound healing activity of Cassia occidentalis L. in albino Wistar rats. Int J Integr Biol. 2009;8(1):1-6.

46. Ehrlich HP, Hunt TK. Effect of cortisone and vitamin A on wound healing. Ann Surg. 1968;167(3):324-8. http://dx.doi.org/10.1097/00000658-19680300000004

47. Ilango K, Chitra V. Wound healing and antioxidant activities of the Fruit Pulp of Limonia Acidissima Linn. (Rutaceae) in rats. Trop J Pharm Res. 2010;9(3):223-30. http://dx.doi.org/10.4314/tjpr.v9i3.56281

48. Murthy S, Gautam MK, Goel S, Purohit V, Sharma H, Goel RK. Evaluation of in-vivowound healing activity of Bacopa monniera on different wound model in rats. Biomed Res Int. 2013;29:1-9. http://dx.doi.org/10.1155/2013/972028 ; PMid:23984424 PMCid:PMC3745907

49. Newman RE, Logan MA. The determination of hydroxyproline. J Biol Chem. 1950;184(1):299-306.

50. Kakkar P, Das B, Viswanathan PN. A modified spectrophotometric assay of superoxide dismutase. Indian J Biochem Biophys. 1984;21(2):130-2. PMid:6490072

51. Abu-Zinadah OA. Effects of Watercress oil on thermal and chemical burn injuries in rabbits. Journal of King Abdulaziz University-Medical Sciences. 2008;15(4):3-17. http://dx.doi.org/10.4197/Med.15-4.1

52. Moghaddam ZP, Zolfaghari MR, Ghaemi EA, Mazandarani M, Mansourian AR, Taheri SA. Negative Performance of Root Extract of Onosma dichroanthum Boiss. on the Burn Wound Healing in an Animal Model. Arch Clin Microbial. 2011;2(5):3823-38.

53. Graca C, Freitas CS, Baggio CH, Dalsenter PR, Marques MCA. Mikania laevigata syrup does not induce side effects on reproductive system of male Wistar rats. J Ethnopharmacol. 2007;111(1):29-32. http://dx.doi. org/10.1016/j.jep.2006.10.039; PMid:17150320

54. Ukwuani AN, Abubakar MG, Hassan SW, Agaie BM. Toxicological studies of hydromethanolic leaves extract of Grewia crenata. Int J Pharm Sci Drug Res. 2012;4(4):245-9.
55. Mukinda JT, Syce JA. Acute and chronic toxicity of the aqueous extract of Artemisia afra in rodents. J Ethno pharmacol. 2007;112(1):138-44. http:// dx.doi.org/10.1016/j.jep.2007.02.011; PMid:17367969

56. Krishnaiah D, Sarbatly R, Nithyanandam RR. A review of the antioxidant potential of medicinal plant species. Food Bioprod Process. 2011;89(3):217-33. http://dx.doi.org/10.1016/j.fbp.2010.04.008

57. Alves CQ, David JM, David JP, Bahia MV, Aguiar RM. Methods for determination of in vitro antioxidant activity for extracts and organic compounds. Quim Nova. 2010;33(10):2202-10. http://dx.doi.org/10.1590/ S0100-40422010001000033

58. Meyer AS, Isaksen A. Application of enzymes as food antioxidants. Trends Food Sci Technol. 1995;6(9):300-4. http://dx.doi.org/10.1016/S09242244(00)89140-2

59. Alam MN, Bristi NJ, Rafiquzzaman M. Review on in vivo and in vitro methods evaluation of antioxidant activity. Saudi Pharm J. 2013;21(2):143-52. http://dx.doi.org/10.1016/j.jsps.2012.05.002; PMid:24936134 PMCid:PMC 4052538

60. Stadelmann WK, Digenis AG, Tobin GR. Impediments to wound healing. Am J Surg. 1998;176:39S-47S. http://dx.doi.org/10.1016/S0002-9610(98)00184-6

61. Kumari M., Eesha BR, Amberkar M, babu S, Rajshekar, Kumar N. Wound healing activity of aqueous extract of Crotalaria verrucosa in Wistar albino rats. Asian Pac J Trop Med. 2010;3(10):783-7. http://dx.doi.org/10.1016/ S1995-7645(10)60187-3

62. Udupa AL, Kulkarni DR, Udupa SL. Effect of Tridax procumbens extracts on wound healing. Int J Pharmacognosy. 1995;33(1):37-40. http://dx.doi. org/10.3109/13880209509088145

63. Roy P, Amdekar S, Kumar A, Singh R, Sharma P, Singh V. In vivo antioxidative property, antimicrobial andwound healing activity of flower extracts of Pyrostegia venusta (Ker Gawl) Miers.J Ethnopharmacol. 2012;140(1):186-92. http://dx.doi.org/10.1016/j.jep.2012.01.008; PMid:22265749

64. Mikhal'chik EV, Anurov MV, Titkova SM, Miroshnikova EA, Lukasheva EV, Deeva IB, et al. Activity of antioxidant enzymes in the skin during surgical wounds. Bull Exp Biol Med. 2006;142(6):667-9. http://dx.doi.org/10.1007/ s10517-006-0446-z ; PMid:17603665

65. Weindl G, Schaller M, Sch"afer-Korting M, Korting HC. Hyaluronic acid in the treatment and prevention of skin diseases: molecular biological, pharmaceutical and clinical aspects. Skin Pharmacol Physiol. 2004;17(5):207-13. http://dx.doi.org/10.1159/000080213; PMid:15452406

66. Su YJ, Chen B, Thang PT, Hughes MA, Xu XL, Cherry GW. Effect of burn healing liquid on keratinocyte and fibroblast proliferation and on collagen lattice contraction. Chin Med J (Engl). 1999;112(8):720-7.

67. Sharma UK, Singh A, Sharma U, Kumar M, Rai D, Agrahari P. Wound healing activity of kigelia pinnata bark extract. Asian J Pharm Clin Res. 2010;3(4):73-5. 


\section{SUMMARY}

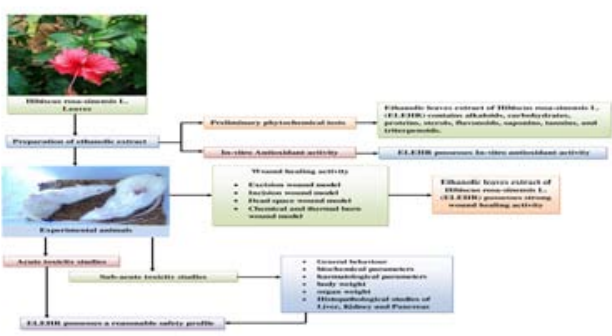

\section{About Authors}

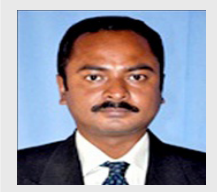

Dr. Sumanta Mondal: (Lecturer \& NSS Programme Officer of GITAM Institute of Pharmacy, GITAM University, Andhra Pradesh, India). His research involves bioactivity and phytochemical studies of various medicinal plant species. He has published more than 48 research articles in various international and national journals. He has guided more than 20 M. Pharm students and presently seven students are pursuing $\mathrm{PhD}$ under his guidance.

\section{SUMMARY}

- The leaves of Hibiscus rosa-sinensis still has not been evaluated for its sub-acute toxicity and wound healing properties although it has been used traditionally for inflammation and skin injuries.

- Potent In-vitro antioxidant activities of ELEHR were observed in all three models i.e., DPPH radical scavenging activity, Nitric oxide (NO) scavenging activity, and Superoxide radical scavenging activity.

- The leaves of Hibiscus rosa-sinensis has a reasonable safety profile, as there was almost negligible abnormalities observed in acute and sub-acute toxicity studies.

- The wound healing properties of leaves of Hibiscus rosa-sinensis were evaluated in four different models i.e., excision, incision, dead space and burn wound model thus a detailed report of wound healing properties is given.

- The results revealed that the leaves of Hibiscus rosa-sinensis possesses potent wound healing activity.

Mr. Debjit Ghosh: Pursuing PhD from Department of Chemistry, GITAM Institute of Science, GITAM University, Visakhapatnam, Andhra Pradesh, India, under the guidance of Prof. K. Rama Krishna and Dr. S. Mondal. His research interest includes isolation and structural elucidation of phyto-constituents, chromatographic and phytochemical analysis, toxicological studies and pharmacological screening. 